\title{
Engineered Sorbent Barriers for Low-Level Waste Disposal
}

\author{
H. D. Freeman \\ S. J. Mitchell \\ J. L. Buelt
}

December 1986

Prepared for the U.S. Department of Energy under Contract DE-AC06-76RLO 1830

Pacific Northwest Laboratory Operated for the U.S. Department of Energy by Battelle Memorial Institute 


\title{
DISCLAIMER
}

This report was prepared as an account of work sponsored by an agency of the United States Government. Neither the United States Government nor any agency thereof, nor Battelle Memorial Institute, nor any of their employees, makes any warranty, expressed or implied, or assumes any legal liability or responsibility for the accuracy, completeness, or usefulness of any information, apparatus, product, or process disclosed, or represents that its use would not infringe privately owned rights. Reference herein to any specific commercial product, process, or service by trade name, trademark, manufacturer, or othenwise, does not necessarily constitute or imply its endorsement, recommendation, or favoring by the United States Government of any agency thereof, or Battelle Memorial Institute. The views and opinions of authors expressed herein do not necessarly state or reflect those of the United States Government or any agency thereof, or Battelle Memorial Institute.

\author{
PACIFIC NORTHWEST LABORATORY \\ operated by \\ BATTELLE \\ for the \\ UNITED STATES DEPARTMENT OF ENERGY \\ under Contract DE-AC06-76RLO 1830
}

Printed in the United States of America

Available from

National Technical Information Service

United States Department of Commerce

5285 Port Royal Road

Springfield, Virginia 22161

NTIS Price Codes

Microfiche A01

Printed Copy

$\begin{array}{lr}\text { Pages } & \begin{array}{r}\text { Price } \\ \text { Codes }\end{array} \\ 001-025 & \text { A02 } \\ 026-050 & \text { A03 } \\ 051-075 & \text { A04 } \\ 076-100 & \text { A05 } \\ 101-125 & \text { A06 } \\ 126-150 & \text { A07 } \\ 151-175 & \text { A08 } \\ 176-200 & \text { A09 } \\ 201-225 & \text { A010 } \\ 226-250 & \text { A011 } \\ 251-275 & \text { A012 } \\ 276-300 & \text { A013 }\end{array}$


H. D. Freeman

S. J. Mitchel 1

J. L. Buelt

December 1986

Prepared for the U.S. Department of Energy under Contract DE-AC06-76RL0 1830

Pacific Northwest Laboratory Richland, Washington 99352 
-

- .

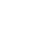




\section{ACKNOWLEDGMENTS}

The authors would like to thank the following individuals for their contributions to this report: Monty Elmore for initial laboratory studies; Lane Bray, Rich Peters, Jack Ryan, Jeff Serne, and John Swanson for consultation; Mike Longaker, Tom Hinkle, and Bill Riemath for performing experimental work; Renie McVeety and Janna Shaw for editing; and Benita Gottsch, Shirley Flink, Debra Perez, and Paulette Goodenough for typing the final manuscript. 
$-$

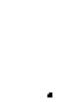




\section{SUMMARY}

The Engineered Sorbent Barriers Program at Pacific Northwest Laboratory is investigating sorbent materials to prevent the migration of soluble radionuclides from low-level waste sites. These materials would allow water to pass, preventing the bathtub effect at humid sites. Laboratory studies identified promising sorbent materials for three key radionuclides: for cesium, greensand; for cobalt, activated charcoal; and for strontium, synthetic zeolite or clinoptilolite. Mixtures of these sorbent materials were tested in 0.6-m-diameter columns using radioactive leachates. To simulate expected worst-case conditions, the leachate solution contained the radionuclides, competing cations, and a chelating agent and was adjusted to a pH of 5 . A sorbent barrier comprised of greensand ( 1 wt $\%$ ), activated charcoal (6 wt $)$ ), synthetic zeolite (20wt\%), and local soil (73 wt $\%$ ) achieved the decontamination factors necessary to meet the regulatory performance requirements established for this study. Sorbent barriers can be applied to shallow-land burial, as backfill around the waste or engineered structures, or as backup to other liner systems. 



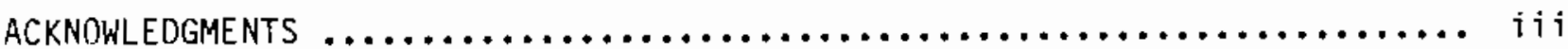

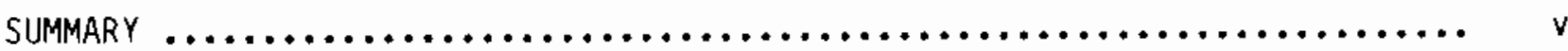

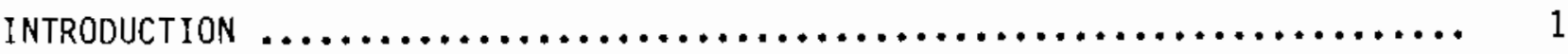

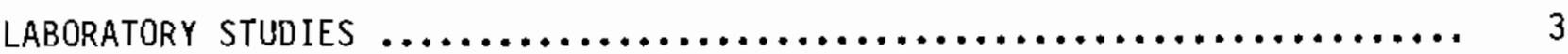

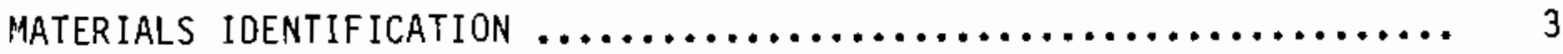

SELECTION CRITERIA $\ldots \ldots \ldots \ldots \ldots \ldots \ldots \ldots \ldots \ldots \ldots \ldots \ldots \ldots \ldots \ldots \ldots \ldots, 4$

Relative Cost-Effectiveness $\ldots \ldots \ldots \ldots \ldots \ldots \ldots \ldots \ldots \ldots \ldots \ldots \ldots, 4$

Long-Term Stability $\ldots \ldots \ldots \ldots \ldots \ldots \ldots \ldots \ldots \ldots \ldots \ldots \ldots \ldots \ldots \ldots \ldots \ldots \ldots \ldots, \quad 5$

Selectivity $\ldots \ldots \ldots \ldots \ldots \ldots \ldots \ldots \ldots \ldots \ldots \ldots \ldots \ldots \ldots \ldots \ldots \ldots, \quad 5$

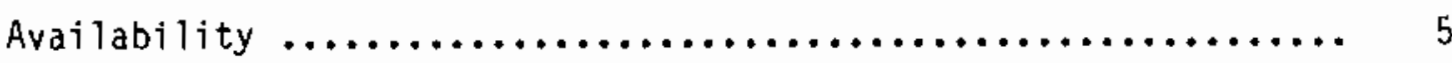

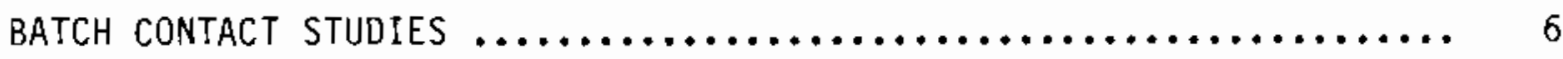

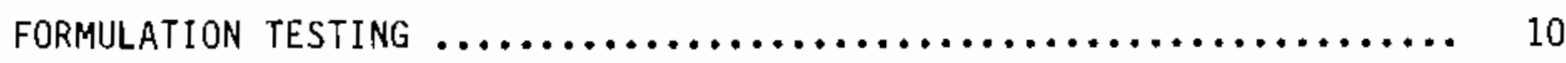

SELECTION OF ADDITIONAL STRONTIUM SORBENTS $\ldots \ldots \ldots \ldots \ldots \ldots \ldots \ldots, 12$

Strontium Precipitants $\ldots \ldots \ldots \ldots \ldots \ldots \ldots \ldots \ldots \ldots \ldots \ldots \ldots, 14$

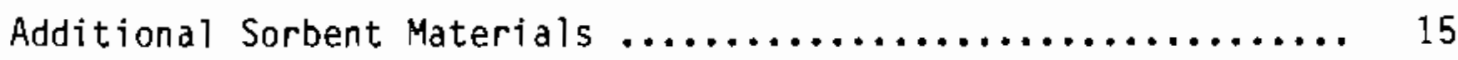

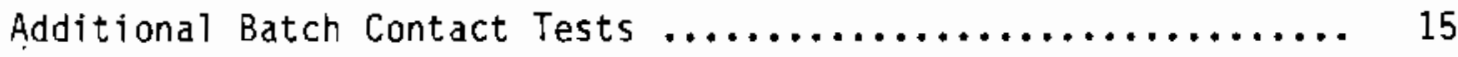

EFFECT OF COMPETING ION CONCENTRATION $\ldots \ldots \ldots \ldots \ldots \ldots \ldots \ldots \ldots \ldots, 18$

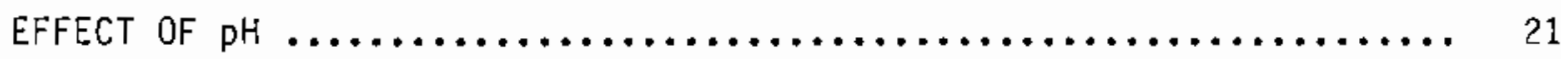

ENGINEERING EVALUATIONS DF SELECTED SORBENT BARRIERS $\ldots \ldots \ldots \ldots \ldots \ldots \ldots .25$

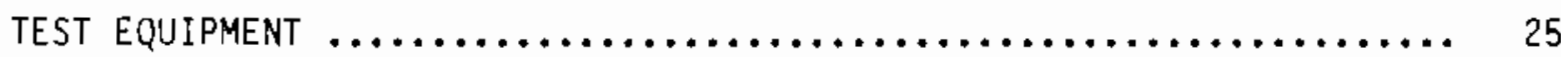

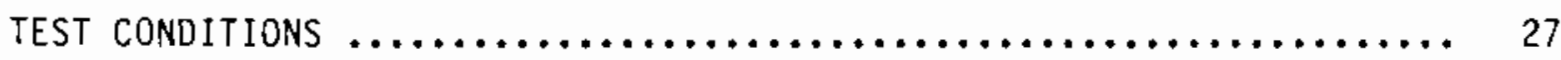

ENGINEERING EVALUATIONS - FIRST SERIES $\ldots \ldots \ldots \ldots \ldots \ldots \ldots \ldots \ldots \ldots \ldots \ldots \ldots \ldots \ldots$

ENGINEERING EVALUATIONS--SECOND SERIES $\ldots \ldots \ldots \ldots \ldots \ldots \ldots \ldots \ldots \ldots \ldots \ldots \ldots \ldots$

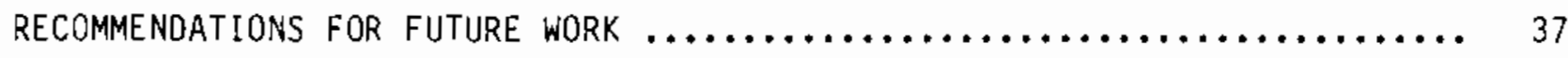


REFERENCES

APPENDIX A - RESULTS OF LABORATORY STUOIES $\ldots \ldots \ldots \ldots \ldots \ldots \ldots \ldots \ldots \ldots \ldots \ldots$

APPENDIX B - RESULTS OF ENGINEERING EVALUATIONS $\ldots \ldots \ldots \ldots \ldots \ldots \ldots \ldots \ldots \ldots$. . 
FIGURES

1 Concentration Versus Time Curves for Batch Contact Tests of Sorbent Barrier Materials ................................. 7

2 Example Results of Tests of Sorbent Barrier Formulations .......... 13

3 Plan View of Equipment for Sorbent Barrier Engineering Evaluations ... 26

4 Exposure Column Used in Engineering Evaluations of Selected Sorbent Barrier Materials ....................................... 27

5 First Series of Engineering Evaluations--Decontamination Factors for Strontium ............................................ 29

6 First Series of Engineering Evaluations--Decontamination Factors for

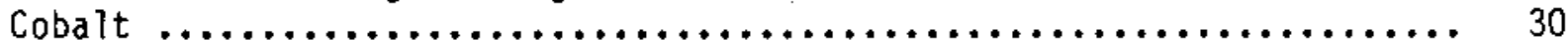

7 First Series of Engineering Evaluations--Core Analysis for Column A .. 31

8 First Series of Engineering Evaluations--Core Analysis for Column B .. 31

9 First Series of Engineering Evaluations--Core Analysis for Column C .. 32

10 Second Series of Engineering Evaluations--Decontamination Factors for

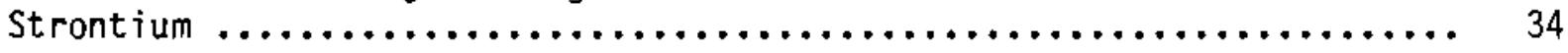

11 Second Series of Engineering Evaluations--Decontamination Factors for Cobalt ............................................. 34

12 Second Series of Engineering Evaluations--Core Analysis for Column A 35

13 Second Series of Engineering Evaluations--Core Analysis for Column B 36

14 Second Series of Engineering Evaluations--Core Analysis for Column C 36 


\section{$\underline{\text { TABLES }}$}

1 Soluble Water Limits and Reduction Factors for Selected Radionuclides 5

2 Distribution Coefficients for Candidate Sorbent Materials, mL/g ..... 9

3 Sorbent Barrier Formulations and Relative Costs $\ldots \ldots \ldots \ldots \ldots \ldots \ldots \ldots$

4 Composition of Leachates Used in Formulation Tests $\ldots \ldots \ldots \ldots \ldots \ldots \ldots . . \ldots$

5 Identification Codes for Materials Tested for Strontium Kd ........ I6

$6 \mathrm{Kd}$ Values for Strontium Sorbent Materials, $\mathrm{mL} / \mathrm{g} \ldots \ldots \ldots \ldots \ldots \ldots \ldots . . . .7$

7 Sorbent Materials Used in Effect of Calcium Concentration Tests ...... i9

8 Effect of Calcium Concentration on Strontium Sorption ............ 20

9 Effect of Calcium Concentration on Cesium Sorption .............. 21

10 Effect of Calcium Concentration on Cobalt Sorption .............. 22

11 Effect of $\mathrm{pH}$ on Kd Values at a Calcium Concentration of $100 \mathrm{ppm} \ldots \ldots . . .2$

12 Effect of $\mathrm{pH}$ on $\mathrm{Kd}$ Values at a Calcium Concentration of $1000 \mathrm{ppm}$..... 24 
INTRODUCTION

This paper describes experimental work on technology for restricting the migration of radionuclides from low-level wastes using sorbent and ion-exchange materials as engineered barriers. Unlike impermeable barriers, sorbent barriers allow moisture to pass while selectively sorbing contaminants. Their sorptive behavior is similar to the ion-exchange properties that many soils possess for certain radionuclides. However, the degree of sorption of radionuclides is dependent on the type of soil, the specific radionuclides, and the presence of competing ions and organics. In many cases, appropriate soils are not available and/or the radionuclides form mobile complexants. Therefore, the use of sorptive soil additives as radionuclide barriers is recommended to prevent radionuclide migration from the waste site.

With relatively impermeable barriers such as membranes or clays, the rate of moisture infiltration could exceed the rate of evapotranspiration and seepage, producing a "bathtub" effect by eventually filling the waste site with water. The resultant over-saturated conditions can create difficulties with waste leachability and waste site stability. Water containing leached radionuclides can spill over the top of the disposal trench and flow away from the site due to the "bathtub" effect. A leachate collection system with continuous maintenance would be required to ensure prevention of the "bathtub" effect.

Sorbent barriers are applicable to a variety of low-level waste isolation situations because of their advantageous radionuclide retention and moisture permeability properties. They may be used as the primary barrier for low-level waste disposal, as a backup to another liner system, or as a backfill around the waste or an engineered structure. Sorbent barrier technology is applicable not only for shallow land burial sites, but also for engineered structures and for deeper disposal practices. Sorbent materials could also be added to the waste itself to improve the waste form. Radionuclides would be more tightly bound in the waste form due to the presence of the sorbent materials.

The experimental work discussed in this paper was directed at the identification and evaluation of sorbent materials for three radionuclides of major concern in defense low-level wastes: cesium-137 $\left({ }^{137} \mathrm{Cs}\right)$, cobalt-60 $\left({ }^{60} \mathrm{Co}\right)$ and 
strontium-90 ( $\left.{ }^{90} \mathrm{Sr}\right)$. The work was conducted over a two-year period in two major phases. The first phase, completed in FY 1985, consisted of laboratoryscale studies of sorbent materials. The second phase, completed in FY 1986, consisted of engineering evaluations of four sorbent barrier formulations in large-scale columns. 


\section{LABORATORY STUDIES}

The objective of the laboratory studies was to: 1) identify potential sorbent materials; 2) develop criteria for selecting materials for testing; 3) obtain distribution coefficients (Kds) from batch contact studies; and 4) test the effectiveness of barrier formulations.

\section{MATER IALS IDENTIFICATION}

During the laboratory studies, several references were reviewed. A number of references cited distribution coefficients for various sorbent materials and soils. However, data pertinent to the conditions of low-level waste sites for a 11 three radionuclides of greatest concern ( $\mathrm{Cs}, \mathrm{Co}$, and $\mathrm{Sr}$ ) at defense sites were not apparent. However, some data on individual radionuclides of concern were available to help select promising materials for the sorbent barriers (Mercer et al. 1978; Schultz 1980; Swanson 1984; Winslow 1986). The sorbent materials originally considered for testing were:

- greensand (glauconite)

- synthetic zeolite, IE-95

- synthetic zeolite, IE-96

- synthetic zeolite, $X-61$

- synthetic zeolite, A-51

- ion-exchange resin Dowex 21-k

- insoluble starch xanthate

- decomplexant DX-2000

- sodium titanate

- carbon sorbate

- activated charcoal

- natural zeolite, clinoptilolite -3

- natural zeolite, clinoptilolite -12

- natural zeolite, clinoptilolite -20

- ion-exchange resin (IRC-718)

- ion-exchange resin (ARC-359)

- ion-exchange resin (Cs-100) 
- vermiculite

- Indian red pottery clay

- ion-exchange resin (XFS-43271.00).

The relative merits of these materials have been briefly discussed by Freeman, Buelt and Hartley (1984). Natural and synthetic zeolites were obvious choices as sorbent materials because they possess desirable properties such as high-exchange capacity, selectivity, and durability. In addition they have been used successfully in the past as ion-exchange material for processing waste water containing radioactive $\mathrm{Cs}$ and $\mathrm{Sr}$ (Winslow 1980).

\section{SELECTION CRITERIA}

Before the results of the laboratory tests could be analyzed, a set of selection criteria had to be developed to rank the relative performance of the sorbent barrier formulations developed in this study. The four criteria are discussed below:

- relative cost-effectiveness

- long-term stability

- selectivity for radionuclides over more prevalent cations

- availability.

\section{Relative Cost-Effectiveness}

The relative cost-effectiveness criterion was based on the cost of the sorbent material required to increase the effective $\mathrm{kd}$ of the $5011 / \mathrm{sorbent}$ material barrier to a value sufficient to meet the U.S. Nuclear Regulatory Conmission (NRC) 10 CFR Part 20, Appendix B, Table II water concentrations for soluble contaminants. The limits and reduction factors required to meet these limits are shown in Table 1. The calculations were based on a 30-cm barrier and a leachate composed of $1 \mathrm{\mu Ci} / \mathrm{L}$ each of ${ }^{137} \mathrm{Cs},{ }^{60} \mathrm{Co}$ and ${ }^{90} \mathrm{Sr}$ (Robertson 1982). A fixed-bed model with sorption by linear equilibrium ion exchange (Winslow 1980) was used to calculate the concentration of the leachate passing through the barrier. 
TABLE 1. Soluble Water Limits and Redyction Factors
for Selected Radionuclides

$\begin{array}{ccc}\text { Radionuclide } & \begin{array}{c}\text { NRC Table I } \\ \text { Limit }(\mu \mathrm{Ci} / \mathrm{mL})\end{array} & \begin{array}{c}\text { Reduction } \\ \text { Factor }(b)\end{array} \\ { }^{60} \mathrm{Co} & 5 \times 10^{-5} & 20 \\ { }^{137} \mathrm{Cs} & 2 \times 10^{-5} & 50 \\ { }^{90} \mathrm{Sr} & 3 \times 10^{-7} & 3333\end{array}$

(a) NRC 10 CFR Part 20, Appendix B, Table II.

(b) Simulated leachate concentration, divided by NRC Table II limit.

\section{Long-Term Stability}

The ion-exchange properties of the sorbent barrier must not degrade significantly with time. A period of about 300 years is necessary to allow radionuclides such as ${ }^{90} \mathrm{Sr}$ and ${ }^{137} \mathrm{Cs}$ to decay to safe levels; after 300 years, the activity of the waste would be reduced by a factor of more than 1000 .

Selectivity

Because the mass of the radionuclides in low-level waste is quite small, it is unlikely that the sorbent capacity of the engineered barrier will be exceeded by sorption of the radionuclides. However, if the sorbent barrier also sorbs other more abundant species such as iron or calcium, these species could load the barrier until it becomes ineffective as a radionuclide sorbent. This consideration is the basis for the selectivity criterion. This criterion will be applied to the sorbent barrier evaluations where the effects of competing ions are being studied.

Availability

The candidate sorbent material must be available in sufficient quantities for use at low-level waste disposal sites. Other sorbent materials that could be generated in larger quantities, pending a demand for the material, will also be considered.

The selection criteria were applied, where appropriate, to the candidate sorbent materials to determine if some materials could be eliminated from 
consideration before laboratory testing began. The long-term stability crite-ria were used to eliminate carbon sorbates, decomplexant DX-2000 and insoluble starch xanthate; none of these materials was considered to be chemically stable for 300 years. Two ion-exchange resins, Cs-100 and ARC-359, were eliminated because they are no longer available in large quantities and are not considered stable for 300 years. The remaining 15 materials were used for the batch con.. tact laboratory studies.

\section{BATCH CONTACT STUDIES}

The batch contact studies were designed to obtain Kd values for the three radionuclides relative to the 15 sorbent materials selected for testing. Dis. tribution coefficients were obtained for two different simulated low-level waste Teachate compositions: with and without ethylenediaminetetracetatic acid (EDTA), a chelating agent. The simulated leachates contained approximately $1 \mu \mathrm{Ci} / \mathrm{L}$ each of ${ }^{137} \mathrm{Cs},{ }^{60} \mathrm{Co}$, and ${ }^{85} \mathrm{Sr}$ at $\mathrm{pH} 5$ (Robertson 1982). The standard leachate contained no EDTA (complexant-forming organic), but the other leachate contained 1 ppm EDTA. Strontium- 85 was used in the simulated leachate insteac of ${ }^{90} \mathrm{Sr}$ to allow all three radionuclides to be measured simuitaneously using gamma spectroscopy.

To derive the Kd values, $200 \mathrm{~mL}$ of simulated leachate were placed in contact with $10 \mathrm{~g}$ of sorbent material. A wrist shaker was used to gentiy mix the leachate and sorbent materials. The shaker was stopped periodically, $20 \mathrm{~mL}$ of solution were sampled and centrifuged, and the solution was analyzed for radionuclides. Radionuclide concentrations were plotted as a function of time to determine the equilibrium solution concentration. The Kd values were calculated from the equilibrium net counts by the following equation:

$$
\mathrm{Kd}(\mathrm{mL} / \mathrm{g})=\frac{\text { (volume solution) }}{(\text { wt material) }} \frac{\text { (initial net counts - fina) net counts) }}{\text { (final net counts) }}
$$

Solution concentration graphs for the more promising sorbent materials along with local and Dak Ridge, Tennessee, soils are shown in Figure 1. A compilation of calculated Kd values for all of the sorbent materials tested in the first phase of the laboratory studies are presented in Table 2. Some of the $\mathrm{Kd}$ 


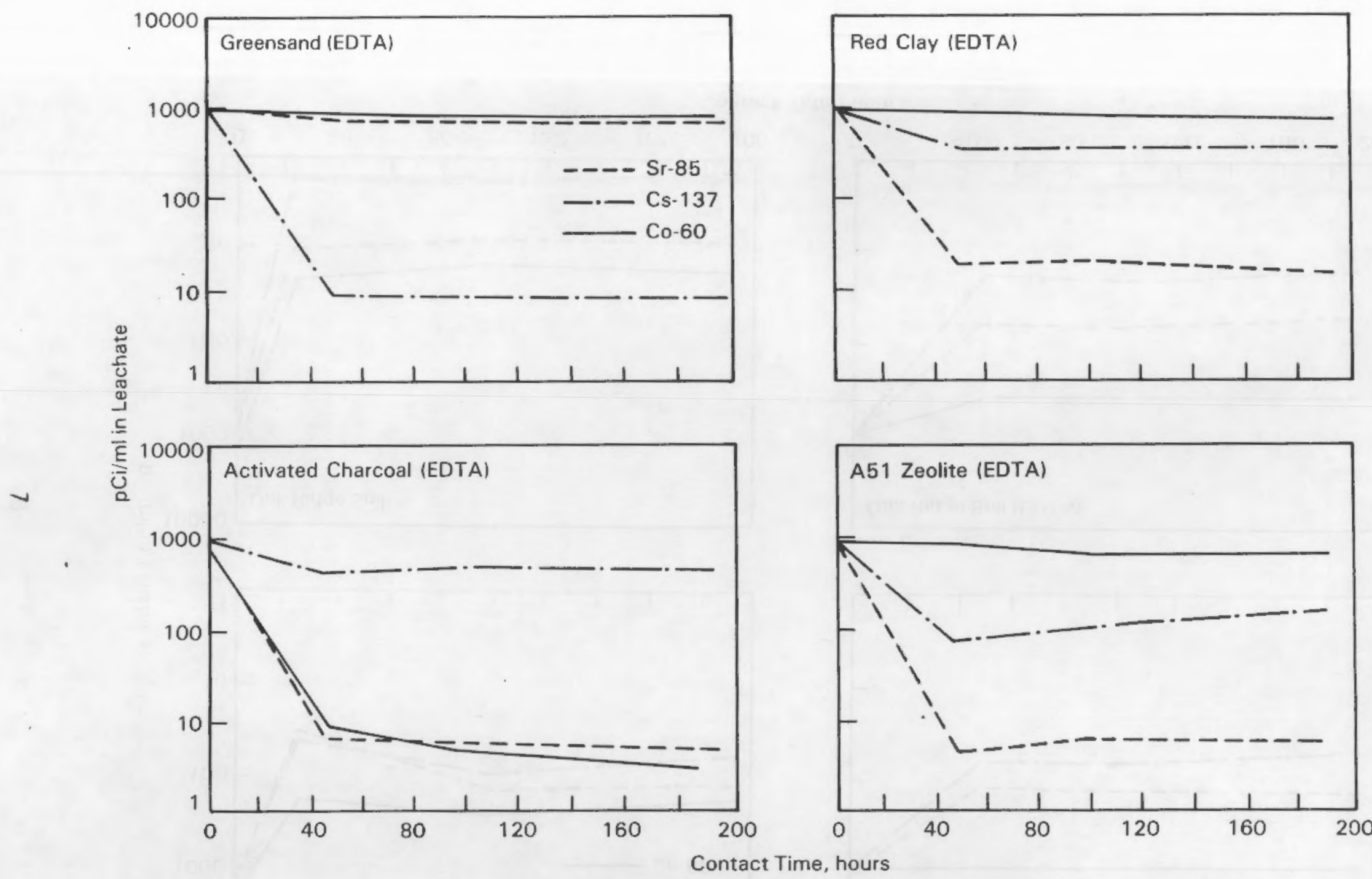

FIGURE 1. Concentration Versus Time Curves for Batch Contact Tests of Sorbent Barrier Materials 


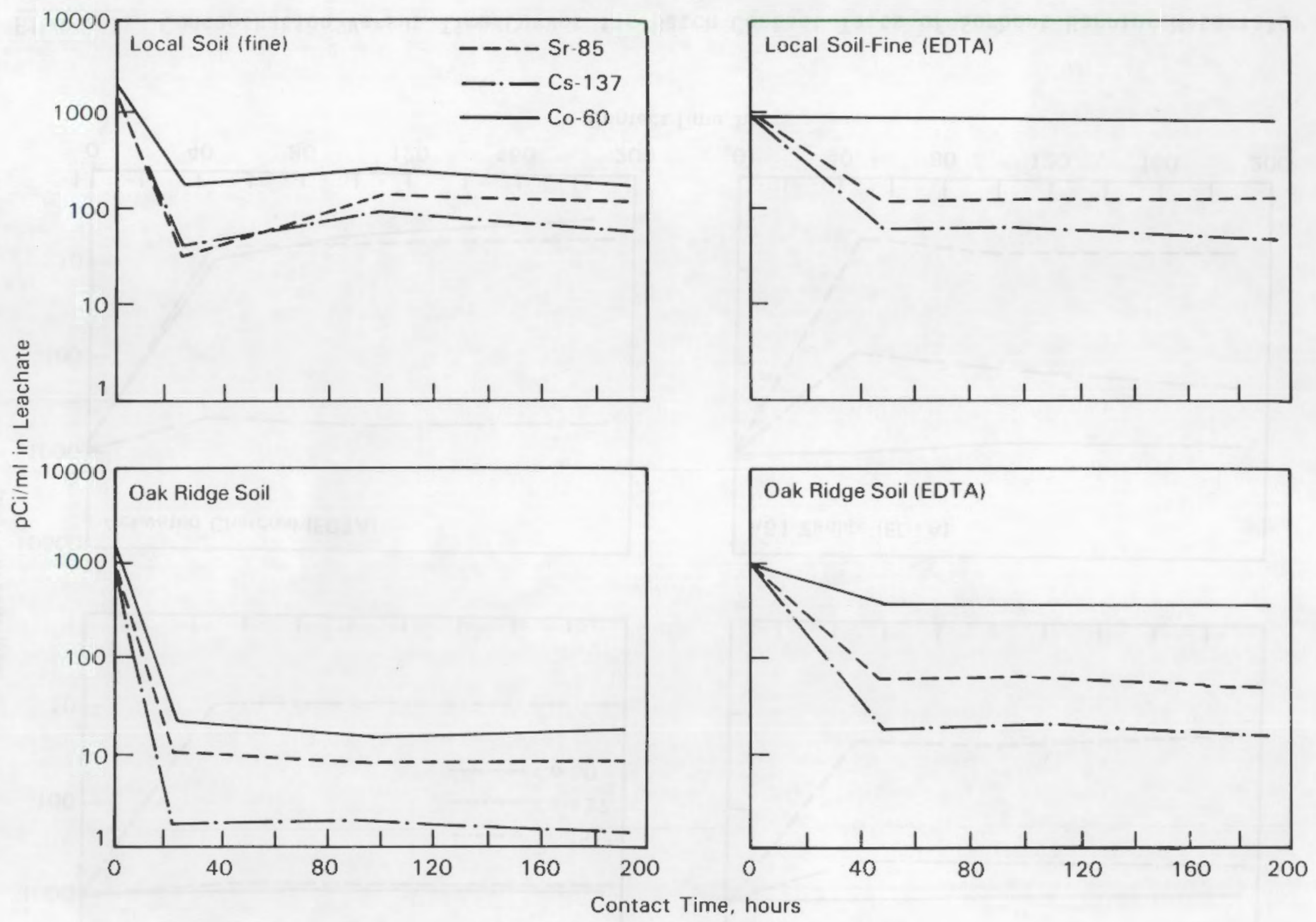

FIGURE 1. (contd) 
TABLE 2. Distribution Coefficients for Candidate Sorbent Materials, mL/g

\begin{tabular}{|c|c|c|c|c|}
\hline Material & Code & $\begin{array}{l}\text { Strontium } \\
\text { Kd Value }\end{array}$ & $\begin{array}{c}\text { Cesium } \\
\mathrm{Kd} \text { Value }\end{array}$ & $\begin{array}{l}\text { Cobalt } \\
\text { Kd Value }\end{array}$ \\
\hline Activated charcoal & $\begin{array}{l}\overline{A C}(\mathrm{a}) \\
{ }^{A} C^{(b)}\end{array}$ & $\begin{array}{r}917 \\
2010\end{array}$ & $\begin{array}{r}8 \\
14\end{array}$ & $\begin{array}{l}1143 \\
4540\end{array}$ \\
\hline Amberlite & AMBR (a) & 1250 & 49 & 6 \\
\hline A-51 zeolite & A51 (a) & $\begin{array}{l}2050 \\
2030 \\
9790\end{array}$ & $\begin{array}{l}31 \\
53 \\
85\end{array}$ & $\begin{array}{r}1 \\
72 \\
3\end{array}$ \\
\hline Clinoptilolite-3 & $\begin{array}{l}\mathrm{CL} 3(\mathrm{a}) \\
\mathrm{CL} 3(\mathrm{~b})\end{array}$ & $\begin{array}{r}241 \\
317\end{array}$ & $\begin{array}{r}00 \\
156\end{array}$ & 11 \\
\hline Clinolite -12 & $\begin{array}{l}\mathrm{CL} 12 \text { (a) } \\
\mathrm{CL} 12 \text { (b) }\end{array}$ & $\begin{array}{l}105 \\
139\end{array}$ & $\begin{array}{l}154 \\
169\end{array}$ & $\begin{array}{r}15 \\
0\end{array}$ \\
\hline Clinolite -20 & $\begin{array}{l}\text { CL20(a) } \\
\text { CL20 (b) }\end{array}$ & $\begin{array}{l}200 \\
268\end{array}$ & $\begin{array}{l}88 \\
76\end{array}$ & $\begin{array}{r}29 \\
1\end{array}$ \\
\hline Dowex $21-\mathrm{K}$ & $\begin{array}{l}D 21 K^{(a)} \\
021 k^{(b)}\end{array}$ & $\begin{array}{r}2 \\
20\end{array}$ & $\begin{array}{r}1 \\
43\end{array}$ & $\begin{array}{r}1 \\
1128\end{array}$ \\
\hline Dowex XFS & $\begin{array}{l}\text { DXFS (a) } \\
\text { DXES (b) }\end{array}$ & $\begin{array}{l}778 \\
333\end{array}$ & $\begin{array}{l}9820 \\
1890\end{array}$ & 9040 \\
\hline Greensand & $\begin{array}{l}\text { GS } \\
G S(b)\end{array}$ & $\begin{array}{l}4 \\
4\end{array}$ & $\begin{array}{l}9950 \\
9490\end{array}$ & 4 \\
\hline Local soil (coarse) & $\begin{array}{l}\operatorname{HSC}_{\text {(a) }} \text { (b) } \\
\mathrm{HSC}^{\prime}\end{array}$ & $\begin{array}{l}84 \\
88\end{array}$ & $\begin{array}{l}171 \\
228\end{array}$ & 98 \\
\hline Local soil (fine) & $\begin{array}{l}\text { HSF (a) } \\
\text { HSF (b) }\end{array}$ & $\begin{array}{l}68 \\
72\end{array}$ & $\begin{array}{l}115 \\
180\end{array}$ & $\begin{array}{r}72 \\
1\end{array}$ \\
\hline IE-95 zeolite & $\begin{array}{l}\text { IE95(a) } \\
\text { IE95(b) }\end{array}$ & $\begin{array}{r}890 \\
1020\end{array}$ & $\begin{array}{l}249 \\
370\end{array}$ & 292 \\
\hline IE-96 zeolite & $\begin{array}{l}\text { IE96 (a) } \\
\text { IE96 (b) }\end{array}$ & $\begin{array}{l}305 \\
458\end{array}$ & $\begin{array}{l}187 \\
307\end{array}$ & $\begin{array}{r}28 \\
1\end{array}$ \\
\hline Oak Ridge soil & $\begin{array}{l}\operatorname{ORS}(\mathrm{a}) \\
\operatorname{ORS}(\mathrm{b})\end{array}$ & $\begin{array}{r}1265 \\
970\end{array}$ & $\begin{array}{l}9950 \\
9490\end{array}$ & $\begin{array}{r}1143 \\
14\end{array}$ \\
\hline Red clay & $\begin{array}{l}R C^{(a)} \\
R C^{(b)}\end{array}$ & $\begin{array}{l}121 \\
127\end{array}$ & $\begin{array}{l}4905 \\
1890\end{array}$ & $\begin{array}{r}4515 \\
?\end{array}$ \\
\hline Sodium titanate & $\mathrm{NaTi}_{i}$ (a) & $\begin{array}{r}15 \\
317\end{array}$ & $\begin{array}{r}1090 \\
81 \\
180\end{array}$ & 17 \\
\hline Vermiculite & $\begin{array}{l}\text { VER }(a) \\
\text { VER }(b)\end{array}$ & 384 & 139 & 141 \\
\hline$x-61$ zeolite & $\begin{array}{l}x 61(a) \\
x 61(b)\end{array}$ & $\begin{array}{l}6290 \\
2050\end{array}$ & $\begin{array}{l}51 \\
49\end{array}$ & $\begin{array}{r}155 \\
0\end{array}$ \\
\hline
\end{tabular}

(a) Standard leachate ( $1 \mu \mathrm{Ci} / \mathrm{L}$ each of cesium, cobalt, and strontium). (b) Leachate with 1 ppm EDTA. 
values shown may be smaller than the actual values. The detection limit of the gamma spectroscopy system was typically $6 \mathrm{pCi} / \mathrm{mL}$ for ${ }^{85} \mathrm{Sr}, 10 \mathrm{pCi} / \mathrm{mL}$ for ${ }^{137} \mathrm{Cs}$, and $1 \mathrm{pCi} / \mathrm{mL}$ for ${ }^{60} \mathrm{Co}$. If the contacted leachate concentrations were below these detection limits, the actual Kd would be greater than those shown.

The $K d$ values for the worse-case EDTA leachate and the unit costs of the sorbent materials were used to calculate the most cost-effective barrier formulations that would result in a leachate concentration past the engineered barrier below the NRC Table II limits. The leachate concentrations exiting the barrier were calculated using the model reported in Winslow (1980). The overall effective $\mathrm{Kd}$ for the barrier was assumed to be a weighted average of the Kds for each of the components in the barrier. More complicated models incorporating nonlinear effects may be used in future barrier design.

Six sorbent barrier formulations were selected for laboratory testing. The barrier formulations and approximate material costs per $\mathrm{m}^{3}$ of barrier are presented in Table 3. The total installed costs of the barriers have not been estimated at this stage of the study. Activated charcoal was the only sorbent material that was effective in sorbing ${ }^{60}$ Co complexed with EDTA. Hence, to meet the NRC Table II limits, it was included in each formulation.

\section{FORMULATION TESTING}

The formulation tests were designed to test the effectiveness of the barrier formulations on a small scale under a variety of conditions. The major parameters included the effect of increased radionuclide concentration and the addition of competing ions to simulate the expected worst-case conditions at a low-level waste site. Four leachates were used to qualitatively investigate the effects of different radionuclide and competing ion concentrations. The compositions of the four simulated leachates are presented in Table 4.

For the formulation tests, each of the six sorbent barrier formulations listed in Table 3 was packed into four $30-\mathrm{mL}$ syringes and placed on a mechanical extractor. The mechanical extractor pulled simulated leachate solutions through the barriers at a constant rate. The solutions were periodically sampled, centrifuged, and analyzed. 
TABLE 3. Sorbent Barrier Formulations and Relative Costs

\begin{tabular}{|c|c|c|c|}
\hline Cost Ranking & Component & Weight Fraction & Cost, $\$ / m^{3}$ \\
\hline 1 & $\begin{array}{l}\text { Local soil } \\
\text { Activated charcoal } \\
\text { Greensand } \\
\text { A51 zeolite }\end{array}$ & $\begin{array}{l}0.88 \\
0.06 \\
0.01 \\
0.05\end{array}$ & 777 \\
\hline 2 & $\begin{array}{l}\text { Local soil } \\
\text { Activated charcoal } \\
\text { Red pottery clay } \\
\text { A51 zeolite }\end{array}$ & $\begin{array}{l}0.85 \\
0.06 \\
0.05 \\
0.04\end{array}$ & 777 \\
\hline 3 & $\begin{array}{l}\text { Local soil } 1 \\
\text { Activated charcoal } \\
\text { Greensand }\end{array}$ & $\begin{array}{l}0.72 \\
0.26 \\
0.02\end{array}$ & 1165 \\
\hline 4 & $\begin{array}{l}\text { Local soil } \\
\text { Activated charcoal } \\
\text { Red pottery clay }\end{array}$ & $\begin{array}{l}0.68 \\
0.26 \\
0.06\end{array}$ & 1165 \\
\hline 5 & $\begin{array}{l}\text { Local soil } \\
\text { Activated charcoal } \\
\text { Dowex XFS resin }\end{array}$ & $\begin{array}{l}0.69 \\
0.25 \\
0.06\end{array}$ & 1942 \\
\hline (a) & $\begin{array}{l}\text { Dak Ridge soil } \\
\text { Activated charcoal }\end{array}$ & $\begin{array}{l}0.96 \\
0.04\end{array}$ & 5 \\
\hline
\end{tabular}

(a) Although local soil was chosen for use in the formulation tests, a formulation using Oak Ridge soil was included for comparison.

Results of the formulation tests are shown in Figure 2, illustrating the effectiveness of the barriers under conditions of low competing ions. No detectable radionuclides broke through the barriers even after greater than 150 pore volumes. However, the sorbent barriers were not able to sorb enough strontium from solution in the presence of high competing ions. The many orders-of-magnitude greater calcium ( $\mathrm{Ca}$ ) concentration saturated the sorbent materials responsible for the sorption of $\mathrm{Sr}$. The chemistry of $\mathrm{Sr}$ and $\mathrm{Ca}$ are so similar that it is unlikely the barriers can be made specific for $\mathrm{Sr}$ when $\mathrm{Ca}$ is present. 
TABLE 4. Composition of Leachates Used in Formulation Tests

\begin{tabular}{|c|c|c|c|c|}
\hline Component & Leachate 1 & Leachate 2 & Leachate 3 & Leachate 4 \\
\hline${ }^{60} \mathrm{Co}, \mu \mathrm{Ci} / \mathrm{L}$ & 1 & 1 & 100 & 100 \\
\hline${ }^{85} \mathrm{Sr}, \mu \mathrm{Ci} / \mathrm{L}$ & 1 & 1 & 100 & 100 \\
\hline${ }^{137} \mathrm{Cs}, \quad \mu \mathrm{Ci} / \mathrm{L}$ & 1 & 1 & 100 & 100 \\
\hline $\mathrm{Ca}^{++}, \mathrm{ppm}$ & 10 & 1000 & 10 & 1000 \\
\hline $\mathrm{Mg}^{+}, \mathrm{ppm}$ & 10 & 1000 & 10 & 1000 \\
\hline $\mathrm{Na}^{+}, \mathrm{ppm}$ & 10 & 1000 & 10 & 1000 \\
\hline $\mathrm{Fe}^{++}, \mathrm{ppm}^{(\mathrm{a})}$ & $\sim 1$ & $\sim 1$ & $\sim 1$ & $\sim 1$ \\
\hline EDTA, ppm & 1 & 1 & 1 & 1 \\
\hline $\mathrm{pH}$ & 5 & 5 & 5 & 5 \\
\hline
\end{tabular}

(a) The $\mathrm{Fe}$ ions precipitate at a $\mathrm{pH}$ of 5 , resulting in a concentration of $1 \mathrm{ppm}$.

Two barriers were selected for testing in the engineering evaluation studies. Because the effectiveness of all of the barrier formulations tested was similar, cost-effectiveness was used as the selection criteria. The two barriers are:

1. 6 wt\% activated charcoal, 1 wt\% greensand, 5 wt\% A-51 synthetic zeolite, and 88 wt\% local soil.

2. 6 wt\% activated charcoal, 5 wt\% red pottery clay, 4 wt\% A-51 zeolite, and $85 \mathrm{wt} \%$ local soil.

SELECTION OF ADDITIONAL STRUNTIUM SORBENTS

It was apparent from the results of the formulation tests that the presence of high concentrations of $\mathrm{Ca}$ in the low-level waste leachate would significantly reduce the effectiveness of the sorbent barrier for $\mathrm{Sr}$ removal. Therefore, a laboratory study was launched in FY 1986 to identify additional methods and materials for removal of $\mathrm{Sr}$ from the leachate. The new materials would be used in two additional engineering-scale column tests to be run in 

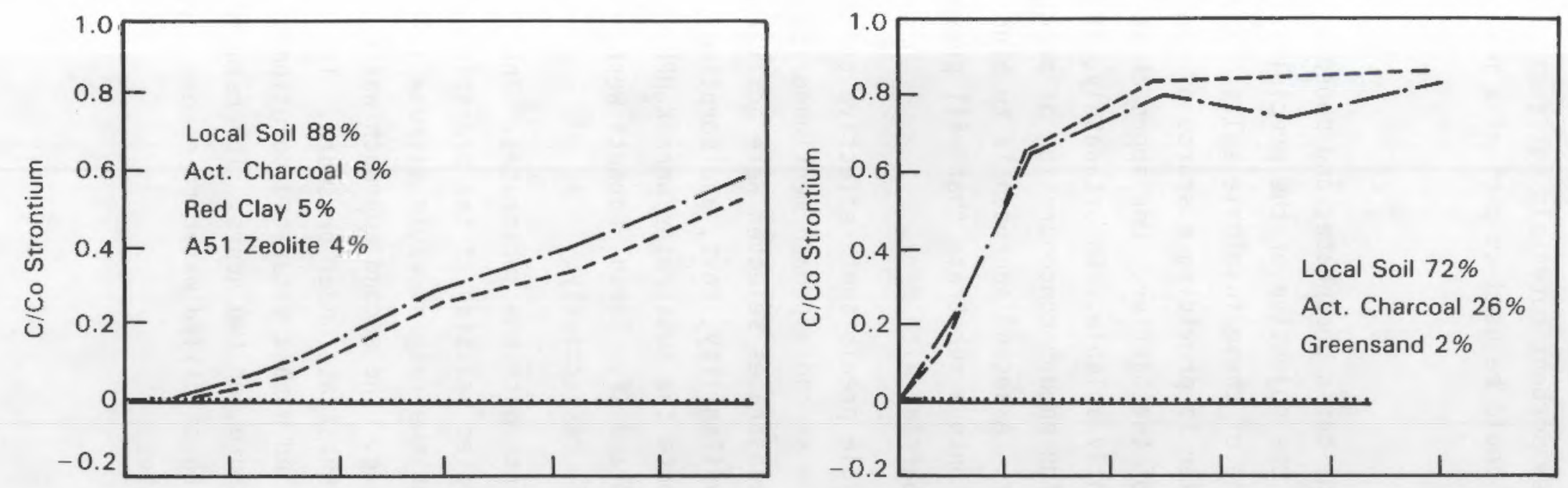

虫
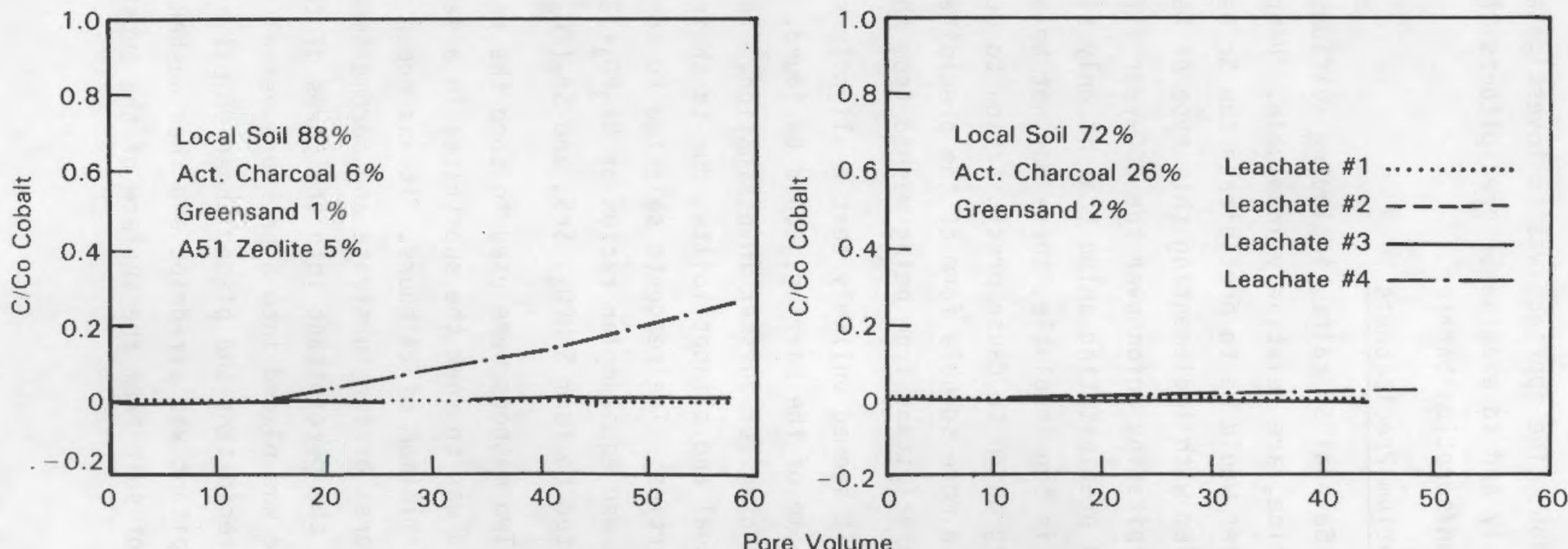

FIGURE 2. Example Results of Tests of Sorbent Barrier Formulations 
FY 1986. The approach was to investigate new sorbent materials not tested previously and to examine Sr precipitants that could be used as part of a precipitation/sorption barrier.

Strontium Precipitants

Several Sr salts, including sulfides, di-basic phosphate, and phosphate/ fluoride, are relatively insoluble. Hence, the objective of the precipitation barrier would be to precipitate the $\mathrm{Sr}$ as one of these insoluble salts. The problem with implementing this type of barrier is providing a source of the precipitating anion over the 300-year life of the barrier. One approach is to use a precipitating anion that is only slightly soluble. Unfortunately, if the salt is too insoluble, there may not be a high enough concentration of precipitating anion to cause precipitation to occur. A second approach is to bind or sorb a more soluble form of the precipitant onto a substrate that will prevent the precipitant from being washed from the barrier with time.

It seemed unlikely that a slightly soluble precipitant, effective over the lifetime of the barrier, could be found. The second approach mentioned above was chosen for further investigation. The substrates selected were activated charcoal and clinoptilolite, due to their availability, cost, and sorption properties. The reagents selected to sorb onto the substrates were $\mathrm{K}_{2} \mathrm{HPO}_{4}$, $\mathrm{Na}_{2} \mathrm{~S}$, and equal molar ratios of $\mathrm{Na}_{3} \mathrm{PO}_{4} \cdot 12 \mathrm{H}_{2} \mathrm{O}$ and $\mathrm{KF}$. These reagents were selected to form $\mathrm{SrHPO}_{4}$, SrS, and $\mathrm{Sr}_{5}\left(\mathrm{PO}_{4}\right)_{3} \mathrm{~F}$, respectively.

Two methods were used to sorb the reagents onto the substrates. The first method was to soak the substrates in a saturated solution of the precipitant for a minimum of 24 hours. It was hoped that the reagent would diffuse into the pores of the substrate and become immobile. The second approach was to force the precipitant into the pores of the substrate under pressure. The substrate was placed into a pressure vessel filled with a saturated solution of the precipitant and placed under $95 \mathrm{psi}$ pressure for two hours. The resultant precipitant was air-dried and then washed with distilled water to remove crystals of salt from the surface of the substrate. 
Additional Sorbent Materials

Review of additional literature and discussions with radionuclide removal experts identified eight new materials with potential for effective sorption of $\mathrm{Sr}$. These materials (and their identification codes) are -20 mesh aluminum hydroxide (AH), AH heated to $400^{\circ} \mathrm{C}$ for four hours, zirconium phosphate (ZP), titanium phosphate (TiP), tin phosphate $(S n P)$, poly antimonic acid (PAA), manganese oxide $\left(\mathrm{MnO}_{\mathrm{n}}\right.$, and titanium $\mathrm{A}$ (TiA). Many of these materials have shown promise as $\mathrm{Sr}$ getters in the Timited use they have had. Their major drawback is that they are quite costly when compared to the sorbent materials tested up to this point.

Additional Batch Contact Tests

The Kd values for the materials discussed above were determined using a similar procedure described for the FY 1985 batch contact studies. Three changes were made to improve the range of Kds that could be measured and to simplify the experimental procedure: 1) the amount of material used in each test was reduced from 10 grams to 1 gram to increase the maximum measurable Kd by an order of magnitude; 2) the materials and leachates were contacted for 72 hours before sampling instead of periodically sampling and analyzing solutions; this resulted in a significant reduction in the number of samples that had to be analyzed; 3 ) the solutions were filtered through a $0.45 \mu m$ millipore filter instead of using a centrifuge. The smaller solids sample size made this feasible. The simulated leachate used in the tests contained competing ions, and consisted of $\sim 1 \mu \mathrm{Ci} / \mathrm{L}^{85} \mathrm{Sr}, 1 \mathrm{ppm}$ EDTA, $1000 \mathrm{ppm} \mathrm{Ca}, 1000 \mathrm{ppm} \mathrm{Na}, 1000 \mathrm{ppm}$ $\mathrm{Mg}$, and $\sim 1 \mathrm{ppm} \mathrm{Fe}$, adjusted to a $\mathrm{pH}$ of approximately 5 . This leachate was selected to represent the expected worst-case conditions at a low-level waste site.

A total of 28 sorbent materials, including 7 materials previously tested, were tested in duplicate using the modified batch contact procedure. The sorbent materials tested and their identification codes are listed in Table 5 . The precipitants that were sorbed onto substrates were tested in the same manner as the other sorbent materials. The Kd values are based on the tota? 
TABLE 5. Identification Codes for Materials Tested for Strontium Kd

Code

Material

Previously Tested Materials

CLl Clinoptilolite from Oregon deposit

CL2 Clinoptilolite from Texas deposit

CL3 Clinoptilolite from Arizona deposit

AC Activated charcoal

A51 A5l synthetic zeolite

IE95 IE95 synthetic zeolite

IE96 IE96 synthetic zeolite

Precipitants on Substrates

ACP Activated charcoal soaked in $\mathrm{K}_{2} \mathrm{HPO}_{4}$

ACPP Activated charcoal pressurized with $\mathrm{K}_{2} \mathrm{HPO}_{4}$

ACS Activated charcoal soaked in $\mathrm{Na}_{2} \mathrm{~S}$

ACSP Activated charcoal pressurized with $\mathrm{Na}, \mathrm{S}$

ACPF Activated charcoal soaked in $\mathrm{Na}_{3} \mathrm{PO}_{4} \cdot 12 \mathrm{H}_{2} \mathrm{O}$ and $\mathrm{KF}$

ACPFP Activated charcoal pressurized with $\mathrm{Na}_{3} \mathrm{PO}_{4} \cdot 12 \mathrm{H}_{2} \mathrm{O}$ and KF

CLP Clinoptilolite soaked in $\mathrm{K}_{2} \mathrm{HPO}_{4}$

CLPP Clinoptilolite pressurized with $\mathrm{K}_{2} \mathrm{HPO}_{4}$

CLS Clinoptilolite soaked in $\mathrm{Na}_{2} \mathrm{~S}$

CLSP Clinoptilolite pressurized with $\mathrm{Na}_{7} \mathrm{~S}$

CLPF Clinoptilolite soaked in $\mathrm{Na}_{3} \mathrm{PO}_{4} \cdot 12 \mathrm{H}_{2} \mathrm{O}$ and $\mathrm{XF}$

CLPFP Clinoptilolite pressurized with $\mathrm{Na}_{3} \mathrm{PO}_{4} \cdot 12 \mathrm{H}_{2} \mathrm{O}$ and $\mathrm{XF}$

New Sorbent Materials

$\begin{array}{ll}\text { AH } & \text { Aluminum hydroxide ( }-20 \text { mesh) } \\ \text { AHH } & \text { Aluminum hydroxide heated to } 400^{\circ} \mathrm{C} \text { for } 4 \mathrm{~h} \\ \text { ZP } & \text { Zirconium phosphate } \\ \text { TiP } & \text { Titanium phosphate } \\ \text { SnP } & \text { Tin phosphate } \\ \text { PAA } & \text { Poly antimonic acid } \\ \text { MnO } & \text { Manganese oxide } \\ \text { TiA } & \text { Titanium A } \\ \text { KP } & \text { Potassium phosphate }\end{array}$

weight of the precipitant and substrate because the effective Kd of the material is needed to design the sorbent barriers. Results of the tests are presented in Table 6 .

Of the 28 materials tested for Sr sorption, only three materials stand out as exceptionally effective: A5l synthetic zeolite, PAA, and MnO. Unfortunately, the two most effective materials, PAA and Mn0, are prohibitively experisive at this time. The forms of the materials used for these tests are only produced in Belgium in limited quantities. However, the cost of the material 
TABLE 6. Kd Values for Strontium Sorbent Materials, mL/g

\begin{tabular}{|c|c|c|c|c|}
\hline \multirow[b]{2}{*}{ Code } & \multicolumn{2}{|c|}{ Run 1} & \multicolumn{2}{|c|}{ Run 2} \\
\hline & $\mathrm{pH}$ & $\mathrm{Kd}$ & $\mathrm{pH}$ & $\mathrm{Kd}$ \\
\hline$C L 1$ & 6.16 & 60.7 & 6.19 & 92.1 \\
\hline CL2 & 6.09 & 60.0 & 6.42 & 84.1 \\
\hline $\mathrm{CL} 3$ & 6.98 & 45.1 & 7.84 & 58.9 \\
\hline$A C$ & 9.28 & 0.0 & 9.38 & 23.7 \\
\hline A51 & 7.05 & 288.2 & 8.64 & 310.8 \\
\hline IE 95 & 6.88 & 43.5 & 7.32 & 71.7 \\
\hline IE96 & 7.41 & 65.1 & 7.72 & 74.0 \\
\hline ACP & 9.13 & 7.1 & 9.16 & 19.7 \\
\hline ACPP & 7.74 & 5.1 & 7.75 & 22.1 \\
\hline ACS & 8.85 & 4.9 & 8.60 & 6.5 \\
\hline ACSP & 9.09 & 0.0 & 9.10 & 29.2 \\
\hline $\mathrm{ACPF}$ & 9.13 & 2.5 & 9.21 & 18.5 \\
\hline ACPFP & 8.91 & 16.5 & 8.93 & 23.2 \\
\hline CLP & 6.79 & 44.8 & 6.88 & 47.9 \\
\hline CLPP & 6.84 & 56.3 & 6.82 & 48.7 \\
\hline CLS & 8.23 & 64.1 & 8.25 & 60.1 \\
\hline CLSP & 8.27 & 71.2 & 8.18 & 71.3 \\
\hline CLPF & 8.41 & 61.1 & 8.41 & 59.0 \\
\hline CLPFP & 8.38 & 69.9 & 8.34 & 68.4 \\
\hline$A H$ & 7.80 & 7.2 & 7.79 & 23.8 \\
\hline $\mathrm{AHH}$ & 7.63 & 12.7 & 7.68 & 32.8 \\
\hline$Z P$ & 2.25 & 13.7 & 2.22 & 30.0 \\
\hline TiP & 2.13 & 6.2 & 2.12 & 31.9 \\
\hline $\mathrm{SnP}$ & 2.97 & 31.4 & 2.97 & 54.6 \\
\hline PAA & 1.96 & 432.7 & 1.94 & 531.5 \\
\hline MnO & 7.00 & 514.4 & 7.35 & 506.4 \\
\hline TiA & 2.68 & 60.1 & 2.67 & 67.0 \\
\hline$K P$ & 6.94 & 69.7 & 7.02 & 84.1 \\
\hline
\end{tabular}


could potentially be reduced substantially if there were sufficient demand. The A5l zeolite is much more reasonable in cost and should be included in future barrier designs. Because of its extremely low cost and fair Kd value, clinoptilolite should also be considered as an effective barrier for $\mathrm{Sr}$.

The precipitation materials did not work as well as hoped. In fact, the presence of the precipitant did not significantly enhance the Kd of the substrate material over what would normally be found. This lack of performance could be due to: a) the particular reagents selected for use in the study or b) more fundamental problems in precipitating very small concentrations of ions from solution.

EFFECT OF COMPETING ION CONCENTRATION

The simulated leachates used in the tests run in FY 1985 and early FY 1986 were designed to simulate the worst expected conditions of competing ions in solution. In reality, these conditions would probably not be found at a significant number of low-level waste sites. To understand the performance of tie sorbent barriers under less severe conditions of competing ions, a set of bat: $h$ contact tests were run where the Ca concentration was reduced to $100 \mathrm{ppm}$ and $10 \mathrm{ppm}$. For comparison, an additional set of tests were also run at the standard conditions of $1000 \mathrm{ppm} \mathrm{Ca}$. For these tests the other competing ions ( $\mathrm{Na}$, $\mathrm{Mg}$, and $\mathrm{Fe}$ ) remained the same as used previously (1000 ppm, $1000 \mathrm{ppm}$, and $1 \mathrm{p} / 3 \pi$ respectively). The batch contact experimental procedure used was the same as that used for the Sr Kd tests in FY 1986. Six sorbent materials were chosen for testing based on previous Kd results. In addition, three natural clays were tested to obtain more data on natural materials. The materials used in these tests are listed in Table 7.

Three series of duplicate tests were run using the three different leach. ates described above (10 ppm Ca, $100 \mathrm{ppm} \mathrm{Ca}$, and $1000 \mathrm{ppm} \mathrm{Ca}$ ). The materials were contacted with the leachates for 72 hours with gentle continuous shaking. The samples were then filtered through a $0.45-\mu m \mathrm{millipore} \mathrm{filter} \mathrm{and} 20 \mathrm{~mL}$ were placed in a vial for analysis. Results of the Kds calculated from the analytical data are presented in Tables 8 through 10 . 
TABLE 7. Sorbent Materials Used in Effect of Calcium Concentration Tests

\begin{tabular}{|c|c|}
\hline Sample ID & Material \\
\hline$A C$ & Activated charcoal \\
\hline $\mathrm{CaB}$ & Calcium bentonite \\
\hline CaM & Calcium montmorillonite \\
\hline $\mathrm{CL} 1$ & Clinoptilolite from Oregon deposit \\
\hline GS & Greens and \\
\hline IRC & Indian red pottery clay \\
\hline $\mathrm{NaM}$ & Sodium montmorillonite \\
\hline LS & Local soil \\
\hline A51 & A5l-zeolite \\
\hline
\end{tabular}

- In general, increasing Ca concentration results in decreasing $\mathrm{Sr}$ Kd values for all materials tested. The magnitude of the decrease, however, varies significantly between materials. For instance, at a Ca concentration of $10 \mathrm{ppm}$, activated charcoal is a fairly good sorbent for $\mathrm{Sr}$ with an average $\mathrm{Kd}$ of $88.1 \mathrm{~mL} / \mathrm{g}$. When the Ca concentration is increased to $1000 \mathrm{ppm}$, the Kd value for activated charcoal decreases to $8.6 \mathrm{~mL} / \mathrm{g}$, by a factor of about 10 . On the other hand, A51 synthetic zeolite decreases by a factor of almost 17 for the same increase in Ca concentration. The decrease in $\mathrm{Kd}$ for A51 zeolite is greater from $100 \mathrm{ppm} \mathrm{Ca}$ to $1000 \mathrm{ppm} \mathrm{Ca}$ than the decrease from $10 \mathrm{ppm} \mathrm{Ca}$ to $100 \mathrm{ppm} \mathrm{Ca}$. These data show that the sorbent barriers will be much more effective for Sr removal under expected average Ca leachate concentrations, less than $100 \mathrm{ppm}$.

The effect of increased Ca concentration was not as dramatic for Cs and Co as it was for $\mathrm{Sr}$. Some noteworthy examples of materials that showed a slight decrease in Cs Kd with increase in Ca concentration from 10 to $1000 \mathrm{ppm}$ are a) clinoptilolite with a $28 \%$ decrease, b) Indian red pottery clay with a $48 \%$ decrease, and c) local soil with a $42 \%$ decrease. These differences in $\mathrm{Kd}$ are not significant, in terms of barrier design. This is due to their high Kd values and relatively low decontamination factors (Df) required to meet the 
TABLE 8. Effect of Calcium Concentration on Strontium Sorption

\begin{tabular}{|c|c|c|c|}
\hline \multirow[b]{2}{*}{ Sample ID } & \multicolumn{3}{|c|}{$\mathrm{Kd}, \mathrm{mL} / \mathrm{g}$} \\
\hline & $10 \mathrm{ppm}$ & $100 \mathrm{ppm}$ & $1000 \mathrm{ppm}$ \\
\hline$A C-A$ & 91.0 & 24.7 & 7.4 \\
\hline$A C-B$ & 85.2 & 29.4 & 9.7 \\
\hline $\mathrm{CaB}-\mathrm{A}$ & 57.4 & 26.5 & 10.8 \\
\hline $\mathrm{CaB}-\mathrm{B}$ & 58.5 & 20.7 & 6.3 \\
\hline CaM-A & 61.7 & 12.3 & 4.8 \\
\hline CaM-B & 50.4 & 20.0 & 3.2 \\
\hline$C L-A$ & 432.7 & 161.8 & 67.1 \\
\hline$C L-B$ & 363.0 & 167.3 & 59.9 \\
\hline $65-A$ & 49.7 & 8.1 & 2.7 \\
\hline $65-B$ & 45.6 & 3.7 & 7.9 \\
\hline IRC - A & 51.3 & 17.1 & 3.3 \\
\hline IRC -B & 54.5 & 14.5 & 1.1 \\
\hline NaM-A & 53.8 & 13.4 & 4.8 \\
\hline NaM-B & 51.8 & 19.0 & 5.7 \\
\hline LS -A & 60.3 & 18.6 & -1.0 \\
\hline LS-B & 53.9 & 9.3 & 5.8 \\
\hline A51-A & 4582.7 & 1762.2 & 271.2 \\
\hline A51-B & 4139.8 & 1676.7 & 247.0 \\
\hline
\end{tabular}

$A$ and $B$ designate duplicate runs.

criteria for this study. The decontamination factor (Of) is the ratio of the initial concentration of a radionuclide in the leachate to the concentration $0^{f}$ the radionuclide exiting the barrier.

The effect of increased Ca concentration on Co Kd values follows a behav.ior that is difficult to explain. Several materials including calcium bentonite, Indian red pottery clay, sodium bentonite, local soil, and A51 zeolite show an increase in $K d$ when the Ca concentration is increased from $10 \mathrm{ppm}$ to $100 \mathrm{ppm}$. However, the materials show a relatively sharp drop in $\mathrm{Kd}$ when the Ca concentration in the leachate is increased from $100 \mathrm{ppm}$ to 
TABLE 9. Effect of Calcium Concentration on Cesium Sorption

\begin{tabular}{|c|c|c|c|}
\hline \multirow[b]{2}{*}{ Sample ID } & \multicolumn{3}{|c|}{$\mathrm{Kd}, \mathrm{mL} / \mathrm{g}$} \\
\hline & $10 \mathrm{ppm}$ & $100 \mathrm{ppm}$ & $1000 \mathrm{ppm}$ \\
\hline$A C-A$ & 41.3 & 24.7 & 30.5 \\
\hline$A C-B$ & 31.8 & 32.2 & 27.6 \\
\hline $\mathrm{CaB}-\mathrm{A}$ & 2083.3 & 1928.0 & 1655.8 \\
\hline $\mathrm{CaB}-\mathrm{B}$ & 1855.6 & 1725.2 & 1411.1 \\
\hline CaM-A & 402.6 & 357.3 & 303.2 \\
\hline CaM-B & 425.7 & 411.2 & 280.7 \\
\hline$C L 1-A$ & 1342.9 & 1064.2 & 925.3 \\
\hline$C L 1-B$ & 1300.2 & 1196.4 & 974.7 \\
\hline GS-A & 7310.2 & 3774.5 & 9664.8 \\
\hline GS'-B & 9655.3 & 6516.8 & 9956.1 \\
\hline IRC $-A$ & 21671.9 & 13619.5 & 9746.3 \\
\hline IRC $-B$ & 19588.9 & 15830.7 & 11657.1 \\
\hline $\mathrm{NaM}-\mathrm{A}$ & 207.3 & 240.5 & 193.8 \\
\hline NaM-B & 245.3 & 230.5 & 192.9 \\
\hline LS-A & 8548.8 & 6111.3 & 4652.8 \\
\hline LS-B & 7921.8 & 6573.5 & 4954.2 \\
\hline$A 51-A$ & 1778.9 & 1102.6 & 1044.6 \\
\hline$A 51-B$ & 1564.6 & 1106.8 & 1040.1 \\
\hline
\end{tabular}

$1000 \mathrm{ppm}$. This "100 ppm peak" is only of academic importance since activated charcoal, the only material effective for cobalt sorption, shows a slight increase in $X d$ with increase in calcium concentration. Hence, a high Ca concentration should not adversely effect the performance of the barrier in sorbing cobalt.

\section{EFFECT OF $\mathrm{pH}$}

Two additional duplicate sets of batch contact tests using the materials in Table 7 were run to determine the effect of increasing the $\mathrm{pH}$ of the simulated leachate from 5 to 7 . One of the reasons for this set of tests was to determine if an error that was made in adjusting the $\mathrm{pH}$ of the simulated 
TABLE 10. Effect of Calcium Concentration on Cobalt Sorption

\begin{tabular}{|c|c|c|c|}
\hline \multirow[b]{2}{*}{ Sample ID } & \multicolumn{3}{|c|}{$\mathrm{Kd}, \mathrm{mL} / \mathrm{g}$} \\
\hline & $10 \mathrm{ppm}$ & $100 \mathrm{ppm}$ & $1000 \mathrm{ppm}$ \\
\hline$A C-A$ & 422.4 & 628.1 & 652.2 \\
\hline$A C-B$ & 422.4 & 594.0 & 569.1 \\
\hline $\mathrm{CaB}-\mathrm{A}$ & 10.2 & 105.5 & 30.2 \\
\hline $\mathrm{CaB}-\mathrm{B}$ & 14.8 & 112.1 & 22.8 \\
\hline CaM-A & 4.8 & 6.7 & 11.1 \\
\hline CaM-B & 4.3 & 14.0 & 3.2 \\
\hline CL1-A & 19.2 & 28.2 & 15.9 \\
\hline CL1-B & 13.6 & 104.6 & 19.0 \\
\hline GS-A & 4.2 & -1.0 & 5.0 \\
\hline GS-B & $1: 3$ & -3.5 & 2.4 \\
\hline IRC -A & 19.0 & 125.0 & 27.6 \\
\hline IRC - B & 12.5 & 137.2 & 23.3 \\
\hline $\mathrm{NaM}-\mathrm{A}$ & 11.4 & 70.4 & 18.2 \\
\hline $\mathrm{NaM}-\mathrm{B}$ & 12.0 & 73.3 & 22.6 \\
\hline LS-A & 4.8 & 30.1 & 16.3 \\
\hline LS-B & 10.9 & 30.0 & 19.5 \\
\hline$A 51-A$ & 32.1 & 209.7 & 36.4 \\
\hline A51-B & 15.1 & 222.0 & 33.6 \\
\hline
\end{tabular}

leachate for the engineering tests (discussed in next section) had affected the: test results. During the first set of engineering evaluations, the $\mathrm{pH}$ had increased from 5 to 7 without adjustment. Two different leachates were used in

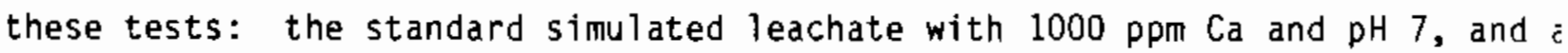
simulated leachate with $100 \mathrm{ppm} \mathrm{Ca}$ and $\mathrm{pH} 7$. The same materials were used in these tests as the tests described in the previous section; consequently, the results from the effect of competing ion tests were used as the pH 5 compariscin for the tests described here. The same procedures as described in the previous section were used for these batch contact tests. The results of these tests (run at pH 7) are compared to the corresponding results for pH 5 in Tables 11 and 12 . 
TABLE 11. Effect of $\mathrm{pH}$ on Kd Values at a Calcium Concentration of $100 \mathrm{ppm}$

\begin{tabular}{|c|c|c|c|c|c|c|}
\hline \multirow[b]{3}{*}{ Sample ID } & \multicolumn{6}{|c|}{$\mathrm{Kd}, \mathrm{mL} / \mathrm{g}$} \\
\hline & \multicolumn{2}{|c|}{${ }^{85} \mathrm{Sr}$} & \multicolumn{2}{|c|}{${ }^{137} \mathrm{Cs}$} & \multicolumn{2}{|c|}{${ }^{60} \mathrm{Co}$} \\
\hline & $\mathrm{pH} 5$ & $\mathrm{pH} 7$ & $\mathrm{pH} 5$ & $\mathrm{pH} 7$ & $\mathrm{pH} 5$ & $\mathrm{pH} 7$ \\
\hline$A C-A$ & 24.7 & 24.4 & 24.7 & 42.6 & 628.1 & 880.0 \\
\hline$A C-B$ & 29.4 & 22.8 & 32.2 & 48.2 & 594.0 & 786.1 \\
\hline $\mathrm{CaB}-\mathrm{A}$ & 26.5 & 29.2 & 1928 & 2065 & 105.5 & 113.8 \\
\hline $\mathrm{CaB}-\mathrm{B}$ & 20.7 & 26.8 & 1725 & 2269 & 112.1 & 114.9 \\
\hline CaM-A & 12.3 & 16.0 & 357.3 & 446.8 & 6.7 & 42.3 \\
\hline CaM-B & 20.0 & 20.8 & 411.2 & 449.5 & 14.0 & 42.5 \\
\hline CL1-A & 161.8 & 207.0 & 1064 & 1167 & 28.2 & 74.0 \\
\hline CLII-B & 167.3 & 193.9 & 1196 & 1250 & 104.6 & 82.0 \\
\hline GS-A & 8.1 & 7.7 & 3774 & 9260 & -1.0 & 35.5 \\
\hline GS-B & 3.7 & 15.7 & 6516 & 10800 & -3.5 & 22.1 \\
\hline IRC-A & 17.1 & 20.5 & 13600 & 24800 & 125.0 & 86.7 \\
\hline IRC - B & 14.5 & -. & 15800 & $\ldots$ & 137.2 & -- \\
\hline $\mathrm{NaM}-\mathrm{A}$ & 13.4 & 18.0 & 240.5 & 254.4 & 70.4 & 47.9 \\
\hline $\mathrm{NaM}-\mathrm{B}$ & 19.0 & 19.2 & 230.5 & 264.3 & 73.3 & 47.8 \\
\hline LS-A & 18.6 & 32.2 & 6111 & 8311 & 30.1 & 95.6 \\
\hline LS-B & 9.3 & 25.7 & 6573 & 9993 & 30.0 & 93.9 \\
\hline A51-A & 1762 & 1785 & 1102 & 1251 & 209.7 & 106.8 \\
\hline A51-B & 1676 & 1920 & 1106 & 1181 & 222.0 & 102.5 \\
\hline
\end{tabular}

The materials of most concern in this test are activated charcoat, greensand, A5l zeolite, Indian red pottery clay, and local soil. These were the materials that made up the first set of engineering evaluation barriers when the $\mathrm{pH}$ adjustment error was made. The only one of these materials that showed a significant difference in Kd with increased $\mathrm{pH}$ was the Indian red pottery clay, which showed a $\sim 50 \%$ increase in Kd when the $\mathrm{pH}$ was increased from 5 to 7. The effect of this result is that the materials in column $B$ were more effective in sorbing $C s$ than would be expected if the proper leachate were used. This fact is of little consequence, however, since Cs was not difficult to sorb in any of the tests. 
TABLE 12. Effect of pH on Kd Values at a Calcium Concentration of $1000 \mathrm{ppm}$

\begin{tabular}{|c|c|c|c|c|c|c|}
\hline \multirow[b]{3}{*}{ Sample ID } & \multicolumn{6}{|c|}{$\mathrm{Kd}, \mathrm{mL} / \mathrm{g}$} \\
\hline & \multicolumn{2}{|c|}{${ }^{85} \mathrm{Sr}$} & \multicolumn{2}{|c|}{${ }_{138} \mathrm{Cs}$} & \multicolumn{2}{|c|}{${ }^{60} \mathrm{Co}$} \\
\hline & $\mathrm{pH} 5$ & $\mathrm{pH} 7$ & $\mathrm{pH} 5$ & $\mathrm{pH} 7$ & $\mathrm{pH} 5$ & $\mathrm{pH} 7$ \\
\hline$A C-A$ & 7.4 & 12.4 & 30.5 & 16.5 & 652.2 & 430.9 \\
\hline$A C-B$ & 9.7 & 14.0 & 27.6 & 31.0 & 569.1 & 474.0 \\
\hline $\mathrm{CaB}-\mathrm{A}$ & 10.8 & 12.6 & 1655 & 1533 & 30.2 & 19.6 \\
\hline $\mathrm{CaB}-\mathrm{B}$ & 6.3 & 9.8 & 1411 & 1683 & 22.8 & 14.2 \\
\hline CaM-A & 4.8 & 9.8 & 303.2 & 289.7 & 11.1 & 7.2 \\
\hline CaM-B & 3.2 & 12.7 & 280.7 & 356.2 & 3.2 & 7.4 \\
\hline CL1-A & 67.1 & 71.3 & 925.3 & 886.0 & 15.9 & -0.1 \\
\hline CL1-B & 59.9 & 70.3 & 974.7 & 897.4 & 19.0 & 22.7 \\
\hline GS-A & 2.7 & 6.3 & 9664 & 8010 & 5.0 & 1.1 \\
\hline GS-B & 7.9 & 10.7 & 9956 & 9500 & 2.4 & -2.9 \\
\hline IRC $-\mathrm{A}$ & 3.3 & 15.8 & 9746 & 15730 & 27.6 & 16.0 \\
\hline$I R C-B$ & 1.1 & 9.8 & 11660 & $1484 D$ & 23.3 & 13.9 \\
\hline NaM-A & 4.8 & 8.2 & 193.8 & 185.6 & 18.2 & 13.8 \\
\hline $\mathrm{NaM}-\mathrm{B}$ & 5.7 & 10.3 & 192.9 & 204.6 & 22.6 & 4.0 \\
\hline LS-A & -1.0 & 11.1 & 4652 & 5230 & 16.3 & 9.7 \\
\hline LS-B & 5.8 & 6.4 & 4954 & 5181 & 19.5 & 9.3 \\
\hline A51-A & 271.2 & 284.9 & 1044 & 1204 & 36.4 & 19.2 \\
\hline$A 51-B$ & 247.0 & 335.7 & $1 D 40$ & 1278 & 33.6 & 18.3 \\
\hline
\end{tabular}


ENGINEERING EVALUATIONS OF SELECTED SORBENT BARRIERS

The purpose of the sorbent barriers engineering evaluations was to verify the performance of the four sorbent barrier formulations identified in the laboratory studies. Since the selection of these barriers was based on experimental results from batch contact interactions and laboratory-scale column studies, field conditions were not adequately represented. In addition, because of the high detection limit in small sample volumes, the laboratoryscale studies did not identify sorption trends under low radionuclide breakthrough conditions. The engineering evaluations were designed to more accurately simulate many field conditions by using large-diameter $(0.6-m)$ columns. The columns simulated water infiltration, physical pressure from the weight of the solid wastes above the sorbent barrier, and hydrostatic head of the leachate expected in the field. The columns also produced larger sample volumes of leachate passing through the sorbent barriers to significantly improve radionuclide analytical detectability. In some cases, the laboratoryscale column studies did not generate enough leachate through the sorbent materials for the radionuclides to be detectable.

The four sorbent materials were tested in two phases in three $0.6-m-$ diameter exposure columns. The first phase exposed two sorbent barrier formulations and one control material (local soil) to radioactive leachates for five months. The second phase tested the two remaining barriers and repeated the testing of the most effective formulation from the first phase tests. The breakthrough of radioactive contaminants was measured under controlled conditions. These measurements were compared with the breakthrough from the control material (local soil) with no sorbent material additions. This approach was taken to conclusively verify the effectiveness of the sorbent material additions.

\section{TEST EQUIPMENT}

The test equipment was arranged as shown in Figure 3. A self-priming pump periodically transferred simulated leachate from 208-L (55-gal) supply drum to the exposure columns. After the leachate had interacted with and flowed 


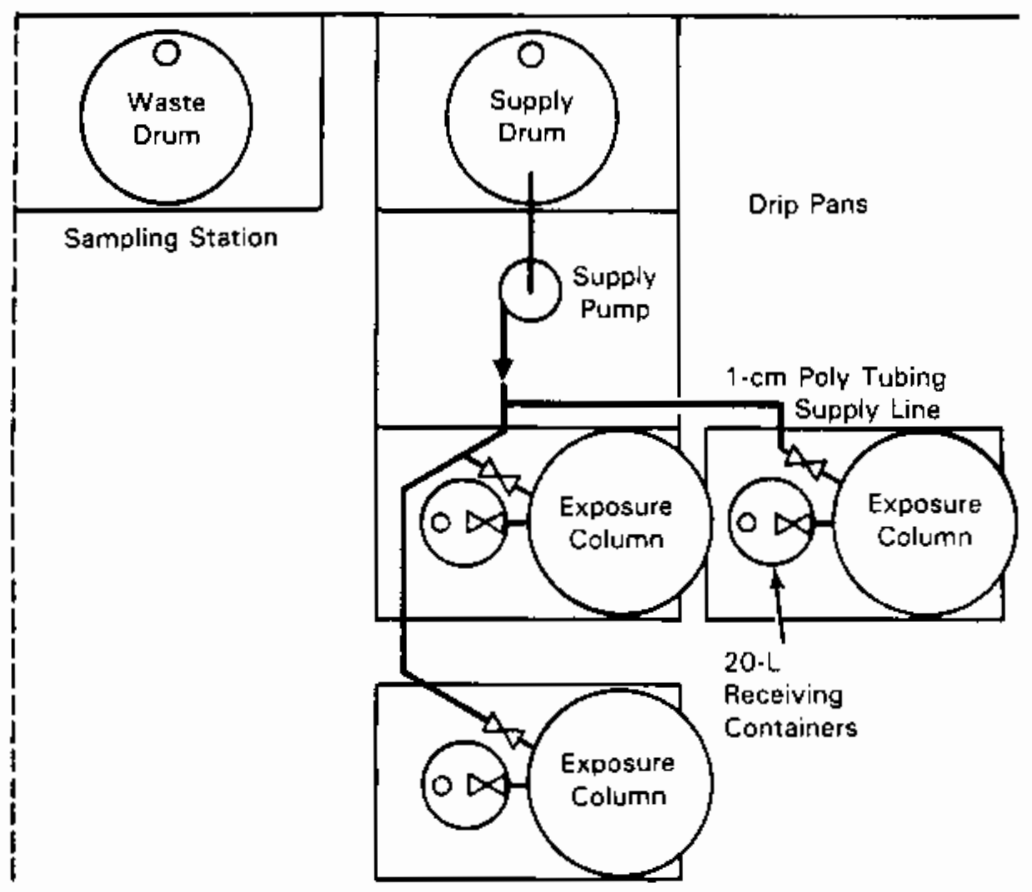

FIGURE 3. Plan View of Equipment for Sorbent Barrier Engineering Evaluations,

through the sorbent barriers in the columns, it was drained through a glass marble and frit sublayer into a 20-L container. A geotextile separated the sorbent material from the glass marble drainage layer. The leachate in the 20-L containers was sampled weekly and transferred to the waste drum at the sampling station.

Each stainless steel exposure column (Figure 4) had a hydraulic piston that simulated the forces exerted on the sorbent barriers by the weight of the overlying soil and solid wastes. Each column was capable of simulating a hydraulic head of leachate over the sorbent barrier by applying a pneumatic pressure of up to $690 \mathrm{kPa}(100 \mathrm{psig})$ to the upper portion of the column. Water infiltration (132 cm of water per year) was simulated by adding the appropriate amount of leachate to the column above the sorbent barrier. Each exposure column had a sight glass in the upper section to determine the leachate level inside the column. To prevent material from entering the sight glass, a fine mesh screen was attached to the inside wall of the exposure column where the sight glass pipe was located. 


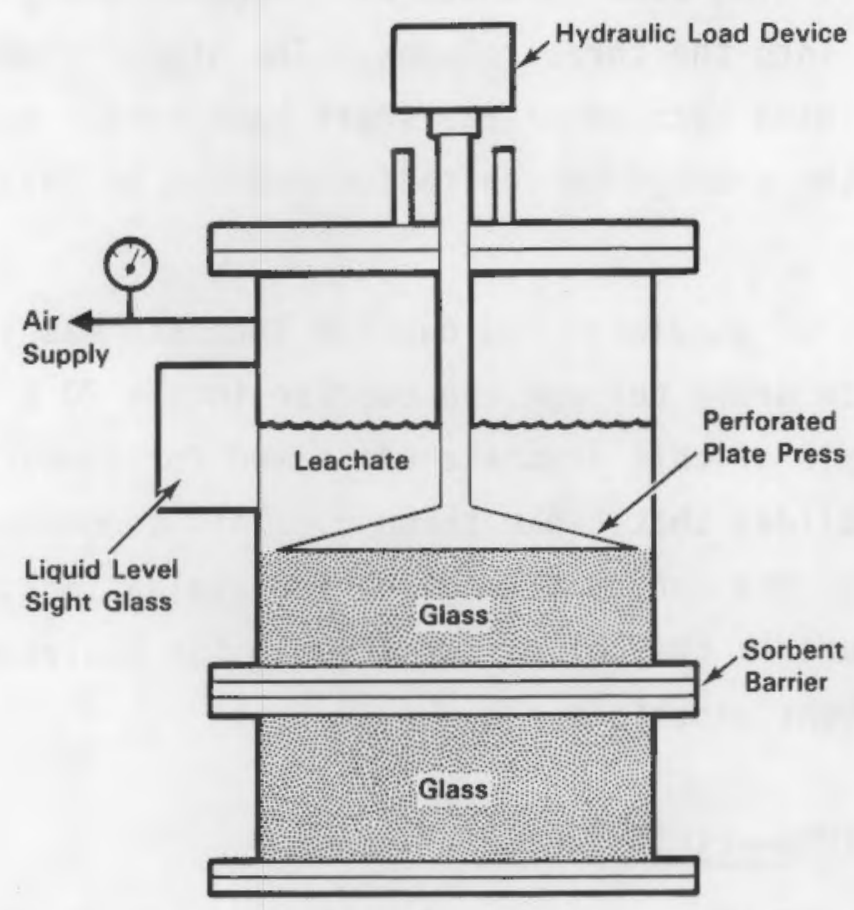

FIGURE 4. Exposure Column Used in Engineering Evaluations of Selected Sorbent Barrier Materials

\section{TEST CONDITIONS}

The simulated leachate was prepared to represent the maximum credible concentrations of $\mathrm{Cs}, \mathrm{Co}_{0}, \mathrm{Sr}$, EDTA, and competing ions expected at a low-level waste disposal site (Robertson 1982). The concentration of each of these components is given below:

- EdTa (1 ppm)

- Ca (1000 ppm, nitrate form)

- $\mathrm{Na}$ (1000 ppm, nitrate form)

- $\mathrm{Mg}$ (1000 ppm, nitrate form)

- Fe (1 ppm, nitrate form)

- concentrated $\mathrm{HNO}_{3}$ (to maintain pH 5)

- ${ }^{85} \mathrm{Sr}$ (1.24 $\mathrm{\mu Ci} / \mathrm{L}$, chloride form)

- ${ }^{60} \mathrm{Co}$ (1 $\mu \mathrm{Ci} / \mathrm{L}$, chloride form)

- ${ }^{137} \mathrm{Cs}$ ( $1 \mu \mathrm{Ci} / \mathrm{L}$, chloride form) 
A 175-L batch of this simulated leachate was prepared every seven weeks for weekly introduction into the three columns. The higher concentration of $1.24 \mu \mathrm{Ci} / \mathrm{L}{ }^{85} \mathrm{Sr}$ was used because of its short half-life. At the end of the seven-week period, the average concentration exposed to the sorbent barriers was $1 \mu \mathrm{Ci} / \mathrm{L}$.

Each week $8.3 \mathrm{~L}$ of simulated radioactive leachate was introduced to each column and allowed to drain through the barrier into a $20 \mathrm{~L}$ leachate collection vessel. A 1-L sample of this leachate was saved for gamma spectroscopy analysis for any radionuclides that broke through. This sequence was repeated for $\sim 21$ weeks for both of the series of engineering evaluations. At the end of the 21 weeks, the barriers in the columns were cored for analysis of radionuclides retained by the sorbent materials.

\section{ENGINEERING EVALUATIONS--FIRST SERIES}

The barrier formulations selected for the first series of engineering evaluations were the most cost-effective based on results of Kd values determined from the laboratory studies. It was expected that these barriers would show premature breakthrough of $\mathrm{Sr}$ since the sorbent barriers were selected prior to the identification of additional Sr sorbents. The three barriers (one control) tested were:

\section{Column A}

5 wt\% A-51 zeolite, 6 wt\% activated charcoal, 1 wt\% greensand, and 88 wt\% local soil (A51/AC/GS/LS).

$\underline{\text { Column B }}$

4 wt\% A-51 zeolite, 6 wt\% activated charcoal, 5 wt\% red pottery clay, and 85 wt\% local soil (A51/AC/RPC/LS).

Column C

100 wt\% local soil (control column).

No Cs breakthrough was observed in any of the columns, including the control column with no sorbent materials added to the soil. Figure 5 shows that Column A performed well for $\mathrm{Sr}$ removal during the entire exposure period. 


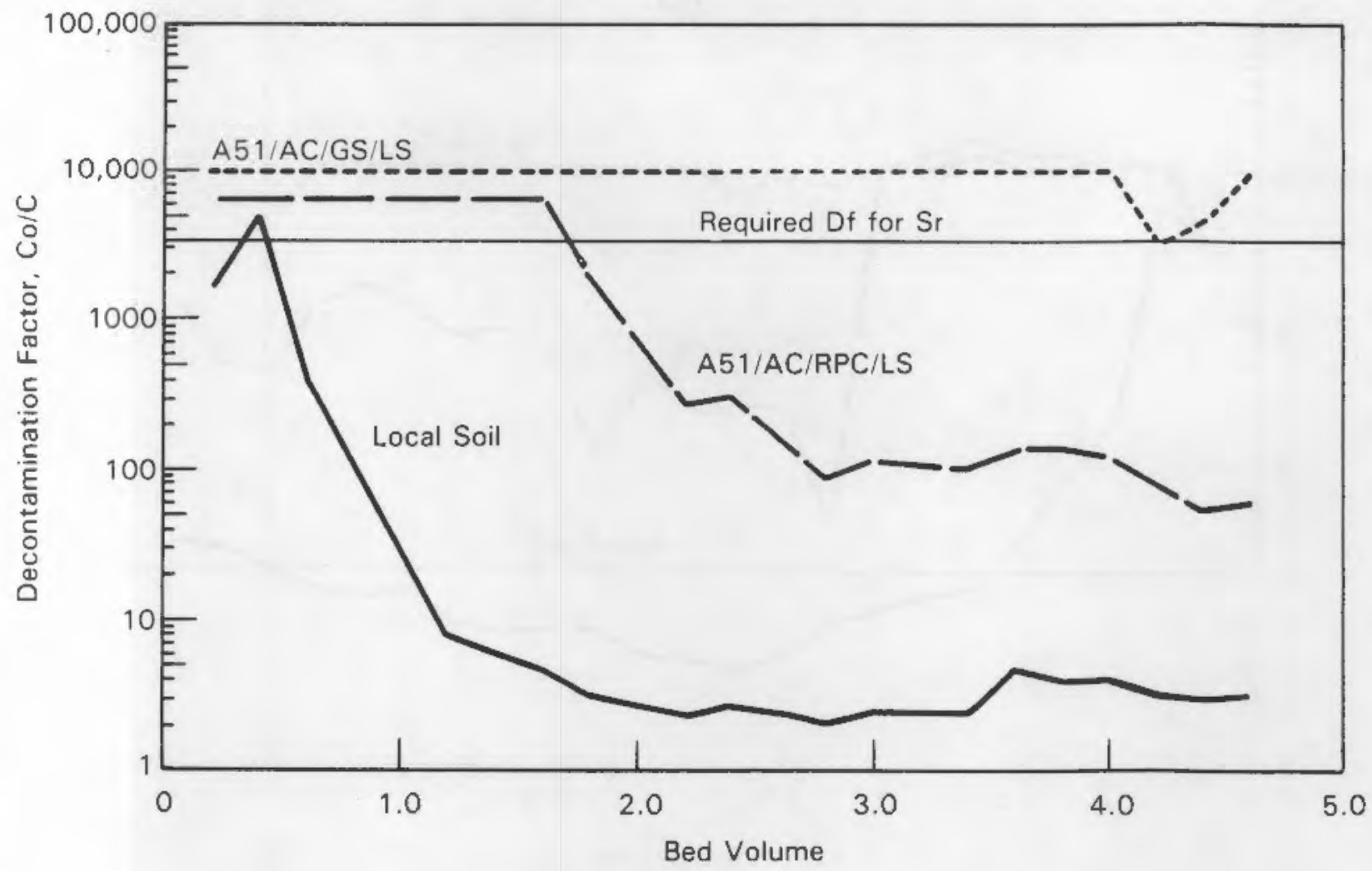

FIGURE 5. First Series of Engineering Evaluations-Decontamination Factors for Strontium

There is only one point that was near the required Df. Column B, however, showed Df below that required after $\sim 1.5$ bed volumes of simulated leachate had passed through. Similarly, the local soil did not meet the required Df except for one point. This illustrates the fact that sorbent barriers are needed to retard $\mathrm{Sr}$ migration in many soils. A properly designed sorbent barrier retards Sr migration greater than 2000 times most soils.

Figure 6 shows that $\mathrm{Co}_{0}$ is not quite as mobile as $\mathrm{Sr}$ for the two barriers tested. Most of the fluctuations in the $\mathrm{Kds}$ for Column A are due to variations in the detection limits. The leachate samples were below the detection limits during most of the sample analyses. The calculated minimum detection limit was used to calculate the decontamination factor in these cases. Both Columns A and $B$ were able to exceed the required decontamination factors for the duration of this test. The fluctuations in the curves make it very difficult to calculate a total capacity for the barriers. Longer-term testing would be required 


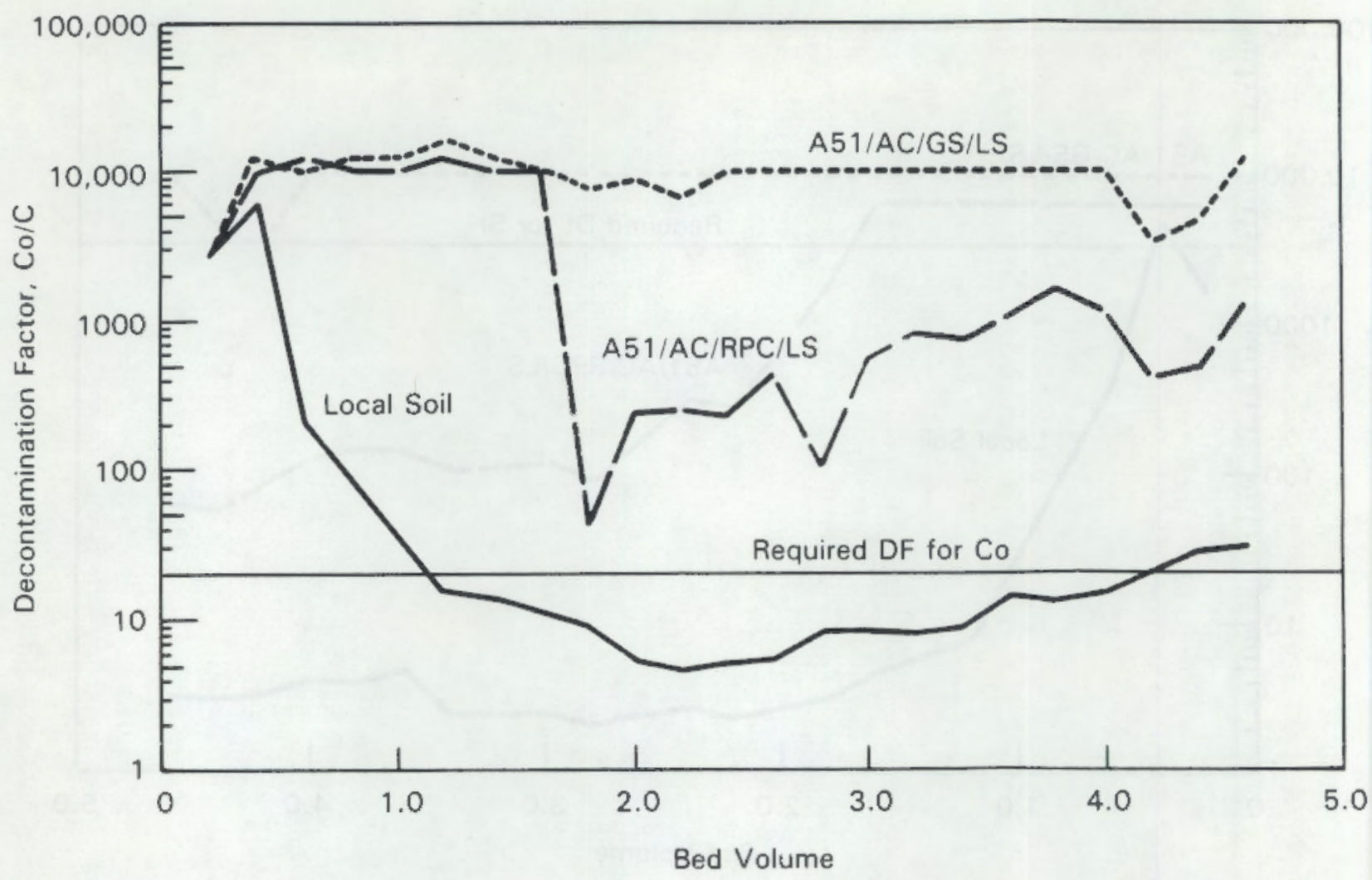

FIGURE 6. First Series of Engineering Evaluations-Decontamination Factors for Cobalt

to reach a point of equilibrium between the leachate and barrier. The soil column (Column C) responded almost identically for $\mathrm{Co}$ as it did for Sr. Again this illustrates the mobility of complexed Co in soils without sorbent material additions.

Seven weeks of testing in addition to the usual 21-week exposure period were performed to correct an error in adjusting the $\mathrm{pH}$ of the simulated leachate solution (from $\mathrm{pH} 7$ to $\mathrm{pH} 5$ ). As discussed in the section on effect of $\mathrm{pH}$, this error was not expected to significantly affect the test results.

At the conclusion of the exposure period, each column was disassembled and two core samples were taken through the thickness of the barriers. These core samples were sectioned, canned and analyzed to give radionuclide concentration profiles through the barriers. These data are shown in Figures 7 through 9.

- As shown in the figures, the largest amount of radioactivity was retained in 


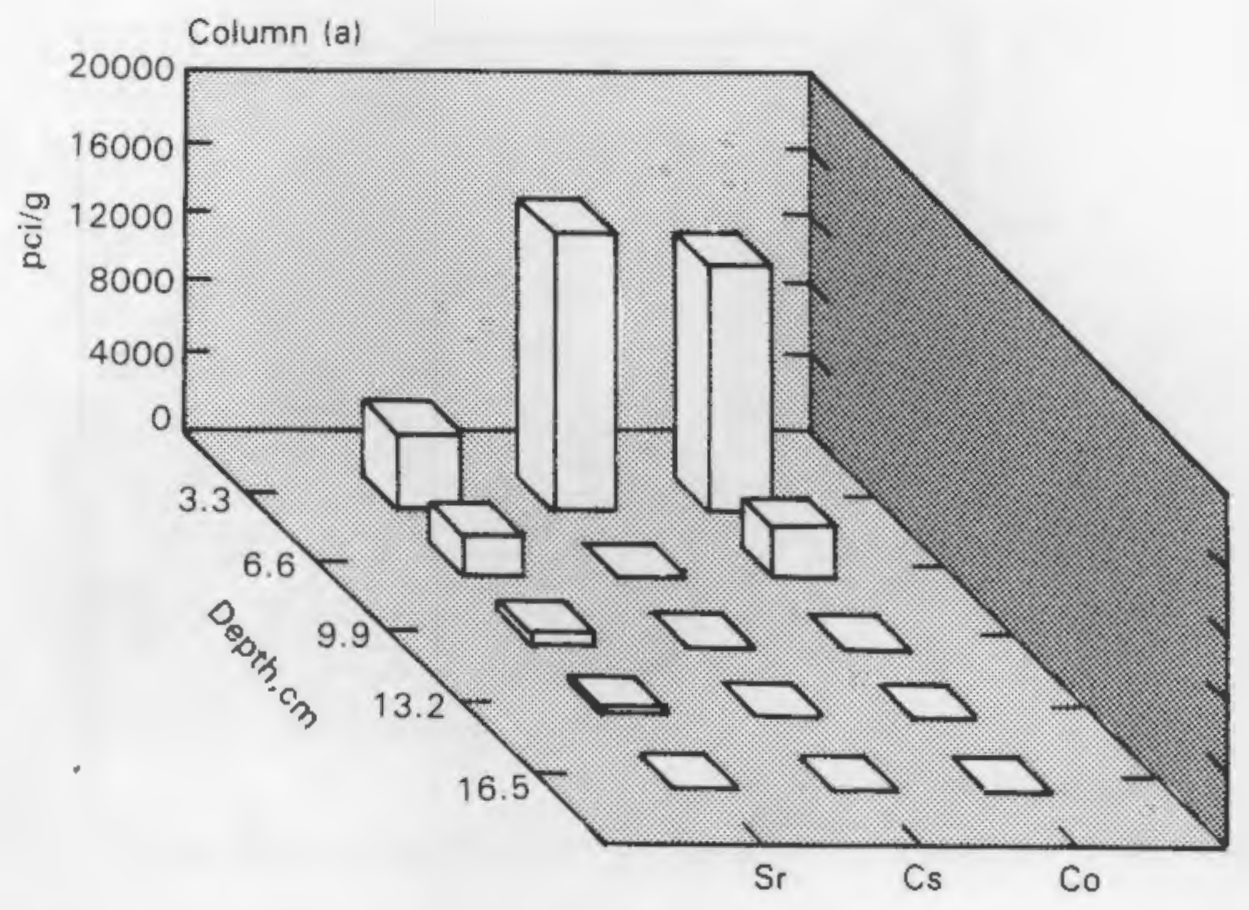

FIGURE 7. First Series of Engineering Evaluations--Core Analysis for Column A

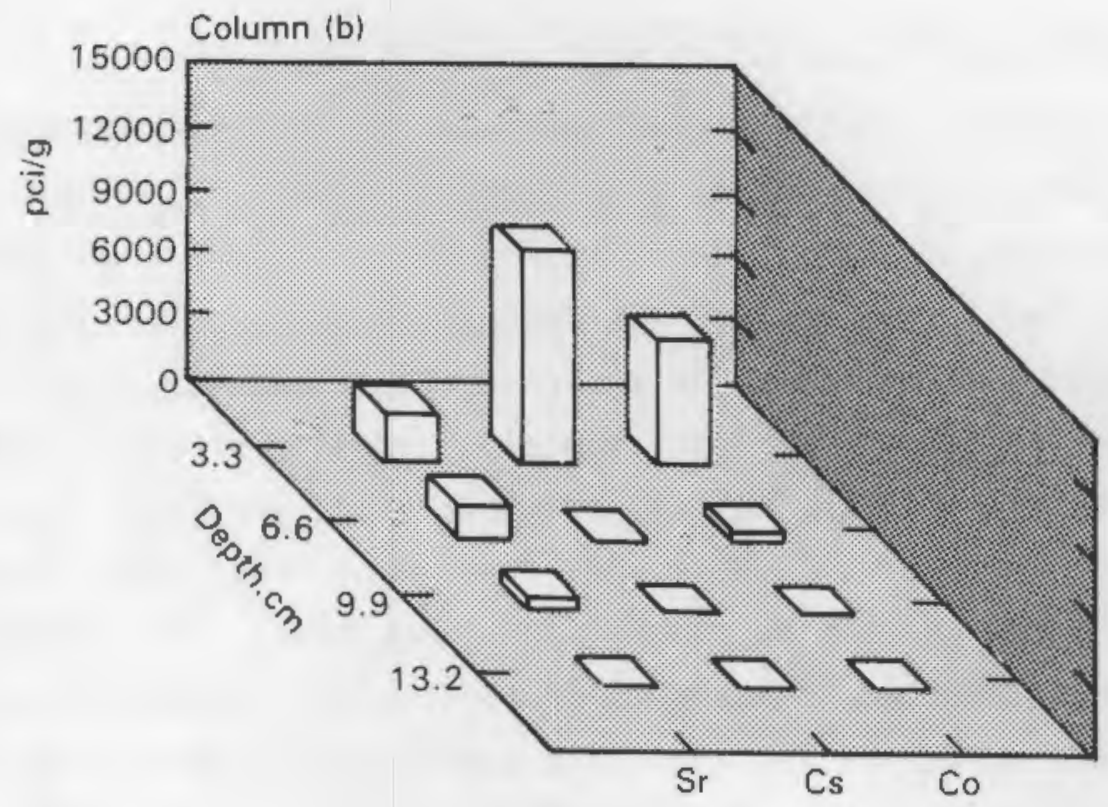

FIGURE 8. First Series of Engineering Evaluations--Core Analysis for Column B 


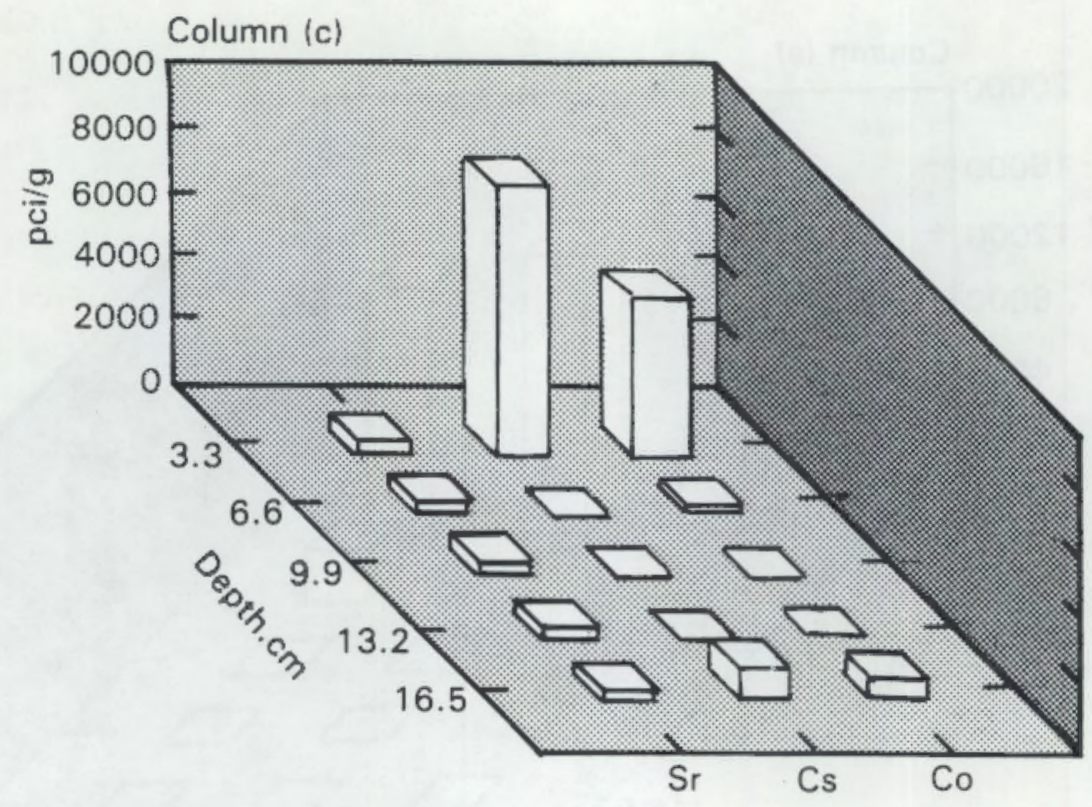

FIGURE 9. First Series of Engineering Evaluations--Core Analysis for Column C

the upper sections of the cores. For $\mathrm{Sr}$, more radioactivity migrated to lower sections; for Column $C$, which had no sorbent material additions, migration of $\mathrm{Sr}$ was not retarded to any extent.

\section{ENGINEERING EVALUATIONS--SECOND SERIES}

The main emphasis of the second series of engineering evaluations was to test two new barriers formulated to be more effective for $\mathrm{Sr}$ removal than those in the first series of tests. The first series of tests showed that Cs and Co could be effectively removed from the leachate solution with greensand and activated charcoal respectively in the presence of maximum credible concentrations of competing ions. The most promising and cost-effective materials for Sr removal identified in the laboratory-scale tests were A-51 zeolite and clinoptilolite. Therefore, formulations containing these materials were tested in the second series of engineering-scale column tests. The concentration of A-51 zeolite was selected to account for Ca loading, to achieve the 300-year lifetime criteria under maximum credible competing ion conditions. The most effective barrier formulation from the first series of tests (containing a 
lower percentage of A-51 zeolite) was repeated to determine repeatability of the resuits. The three formulations tested were:

Column A

20 wt\% A-51 zeolite, 6 wt\% activated charcoal, 1 wt\% greensand, and 73 wt\% local soil (A51(20)/AC/GS/LS).

Column B

93 wt\% clinoptilolite, 6 wt\% activated charcoal, and 1 wt\% greensand (CL/AC/GS).

Column C

(repeat from FY 1985) 5 wt\% A-51 zeolite, 6 wt\% activated charcoal, 1 wt\% greensand, and $88 \mathrm{wt} \%$ local soil (A51(5)/AC/GS/LS).

Samples of the leachates collected from these columns were analyzed and the results are presented in Figures 10 and 11 . No breakthrough for Cs was observed, indicating a $D f$ of $>8000$ for each column. Tabulated values are also presented in Appendix B.

Results showed that one barrier formulation met all the performance requirements established for this study. This formulation was tested in column $A$, and the sorbent materials comprising this barrier were $20 \mathrm{wt} \%$ A-51 zeolite, 6 wt\% activated charcoal, and $1 \mathrm{wt} \%$ greensand. This barrier showed no breakthrough for strontium or cesium and only minor breakthrough for cobalt (within performance requirements).

The clinoptilolite-containing barrier did not perform as predicted by the laboratory-scale experiments (Figure 10). This formulation was tested in column B, and both $\mathrm{Sr}$ and Co broke through the column after a two week exposure period. No Cs was observed in the leachate. The clinoptilolite may not be performing as expected due to insufficient contact time. The barrier is fairly permeable, which allows the leachate to percolate through the barrier at a rapid rate. The rate of percolation could be controlled by using finer clinoptilolite or by adding small amounts of clay to decrease the permeability.

Column $C$, which was a repeat of one of the first series of column tests, showed some breakthrough of $\mathrm{Sr}$ and $\mathrm{Co}$ similar to the previous series results 


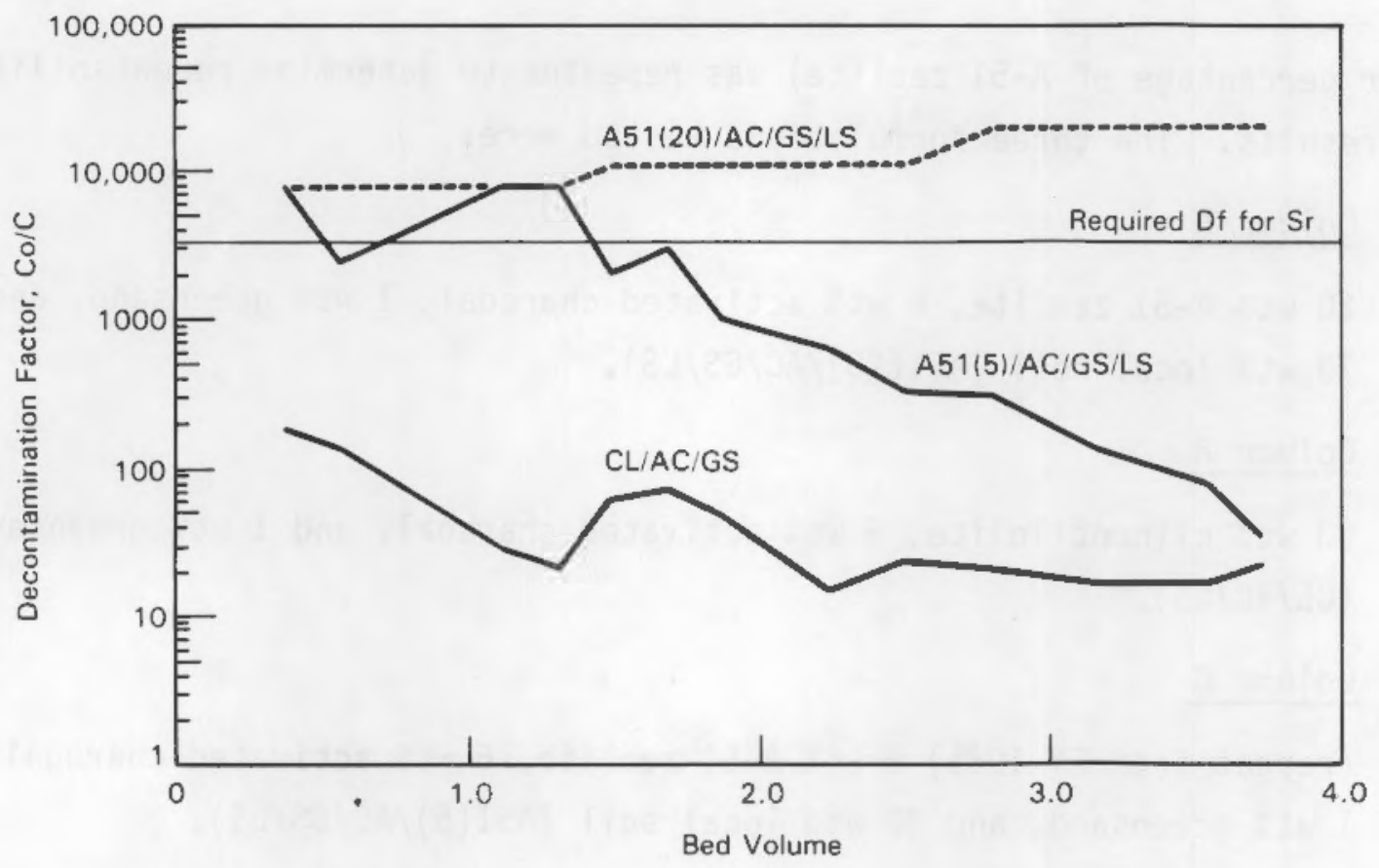

FIGURE 10. Second Series of Engineering Evaluations-Decontamination Factors for Strontium

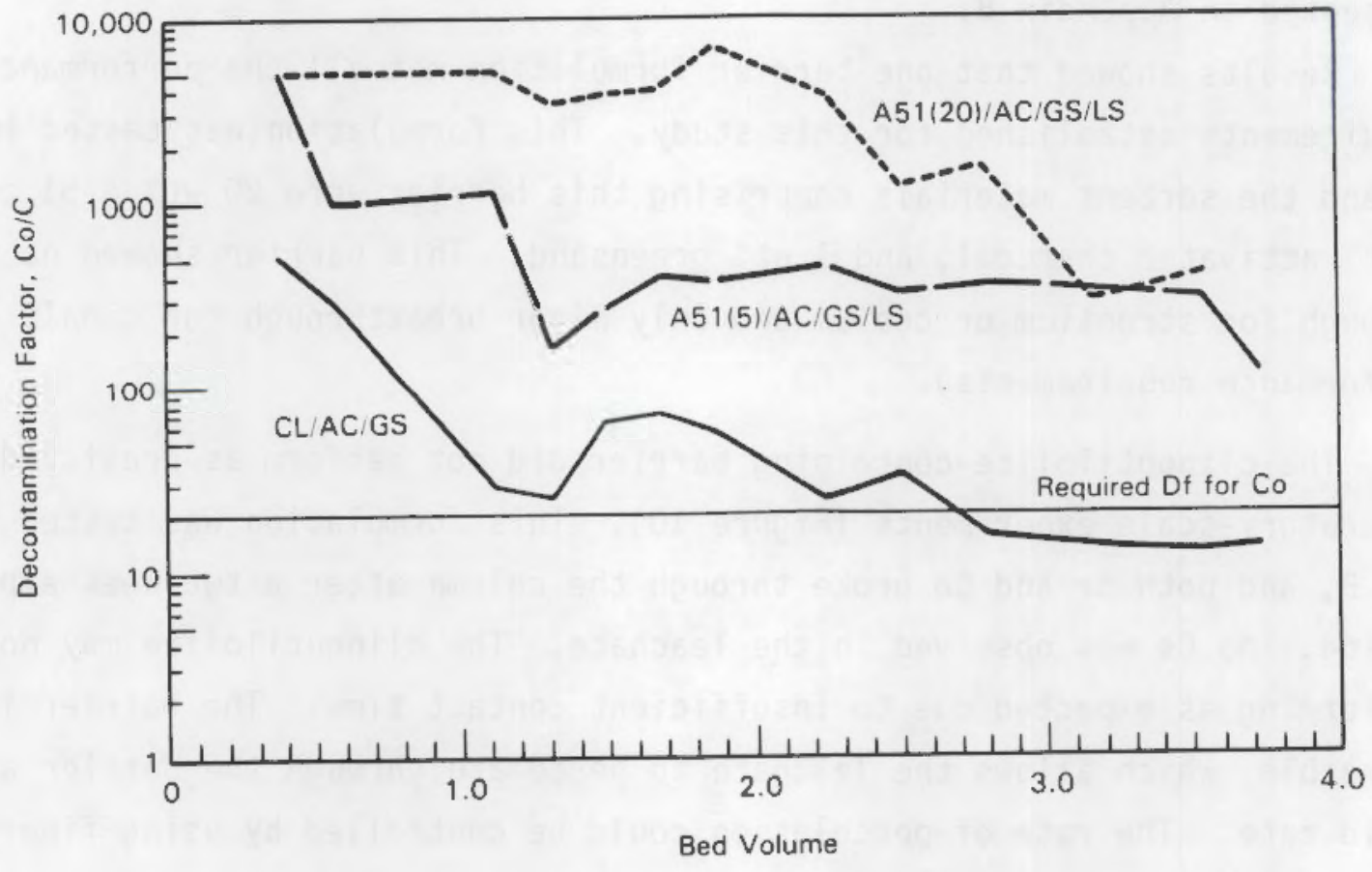

FIGURE 11. Second Series of Engineering Evaluations-Decontamination Factors for Cobalt 
(Figure 7). The higher concentration of A-51 zeolite used in column A (20 wt\%) is necessary for adequate $\mathrm{Sr}$ removal. The composition of column $\mathrm{C}$ was the same except for a lower amount of A-51 zeolite ( $5 \mathrm{wt} \%$ ).

Two core samples were taken from each of the three columns for radionuclide profile analysis, and the columns were dismantled. Results of these core analyses are shown in Figures 12 through 14, and tabulated data are included in Appendix B.

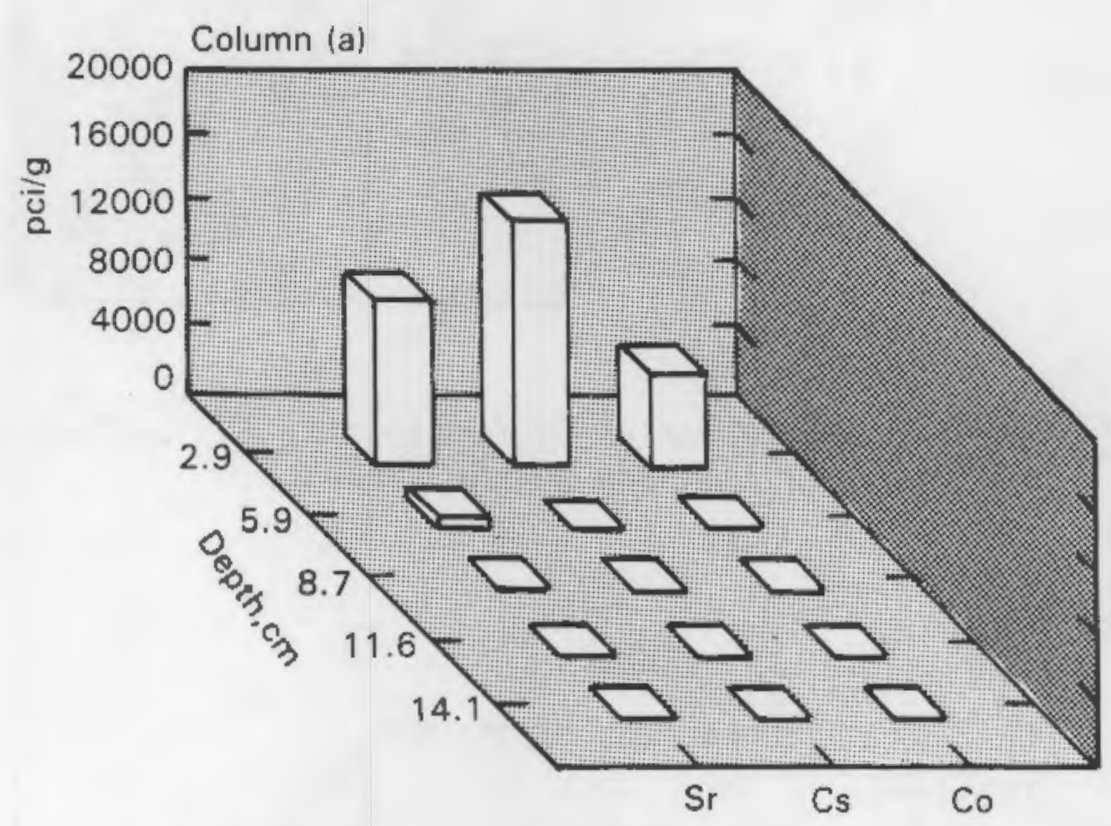

FIGURE 12. Second Series of Engineering Evaluations-Core Analysis for Column A 


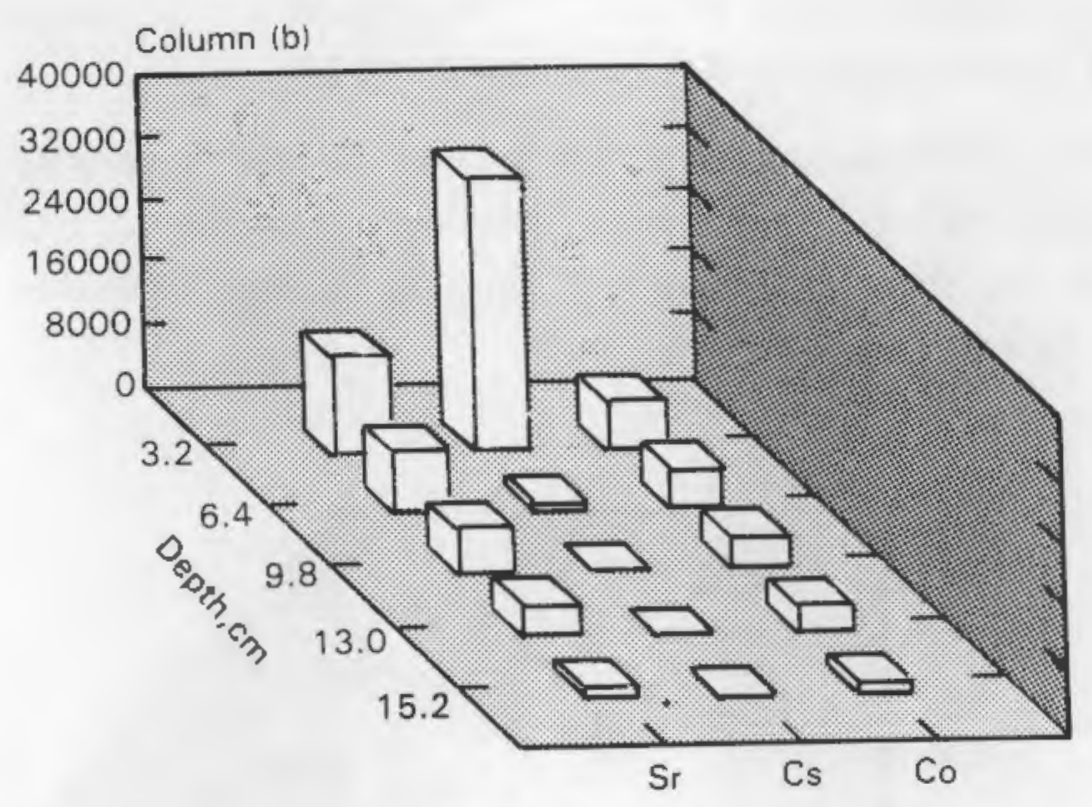

FIGURE 13. Second Series of Engineering Evaluations-Core Analysis for Column B

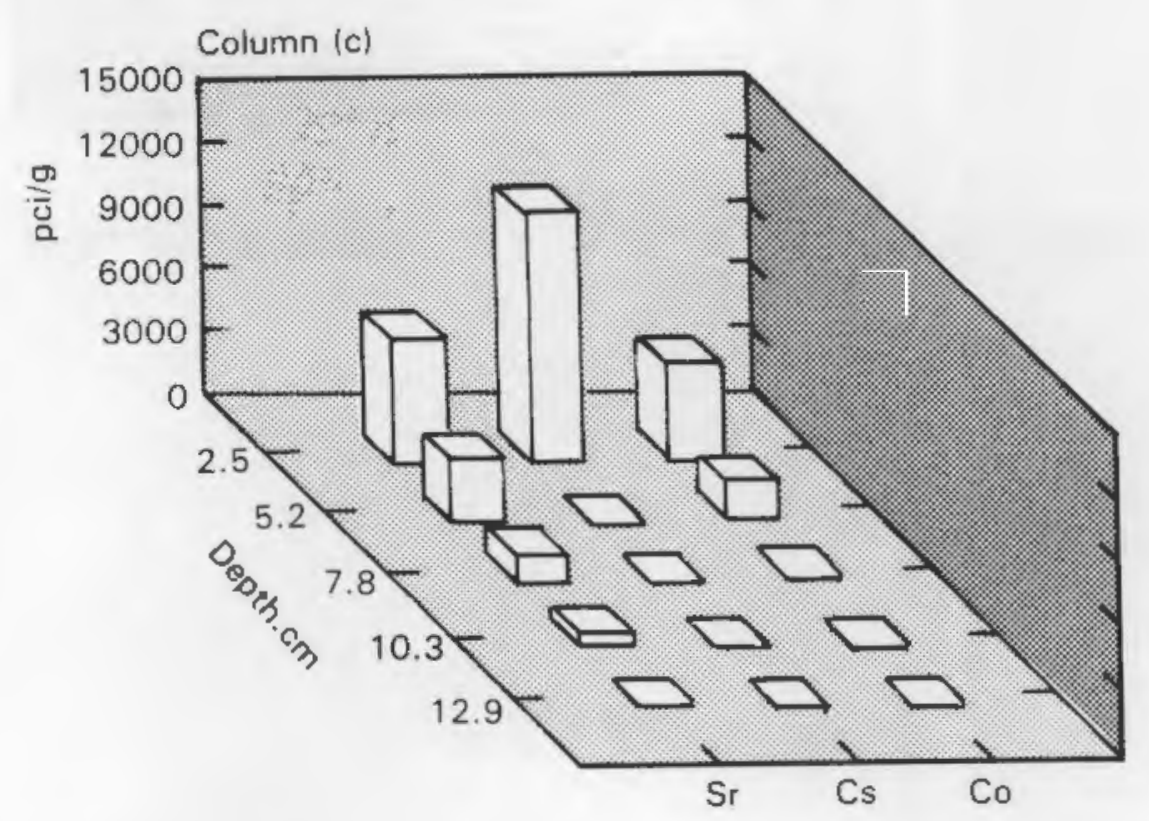

FIGURE 14. Second Series of Engineering Evaluations-Core Analysis for Column C 


\section{RECOMMENDATIONS FOR FUTURE WORK}

This report covers a body of experimenta? work that was primarily designed to identify promising materials for use in sorbent barriers and to evaluate their effectiveness under simulated laboratory- and engineering-scale conditions. Questions that remain to be answered concern the mechanisms involved in radionuclide removal by the sorbent barriers and the total capacity of the barriers for removal of each radionuclide. These points need to be addressed to predict the lifetime expectancy of the barriers, the period of time during which satisfactory performance is maintained. If the barrier capacity was known, the barrier could be designed to have a thickness sufficient to retain the radionuclides for the period of time necessary for decay to innocuous levels (approximately 300 years). After the required barrier thickness is determined, accurate material cost estimates could be prepared for a conceptual sorbent barrier system design.

To address these concerns, experiments on the kinetics and breakthrough characteristics of sorbent barrier systems are recommended. The effects of radionuclide concentration, residence time, and competing ion concentration would be studied. Reversibility of the sorption reaction would be tested to determine if the barriers act in a classical ion exchange manner, as expected. If not, mechanisms such as molecular sieve phenomenon and precipitation would be investigated. Tests would be run to determine if the sorbent barrier mechanism is represented by a linear isotherm or if nonlinearity occurs at higher loadings. These experiments would provide the input necessary to model sorbent barrier systems to predict their lifetime performance.

Before actual implementation of sorbent barrier technology, the demonstration of sorbent barrier performance on a field scale would be required to ensure that the techniques available for barrier installation would not affect performance. Also, field test monitoring must be conducted for a sufficient period of time to extrapolate the data with confidence for the established 300-year criteria period. Sorbent barriers must be designed specifically for 
the waste, soil, climate, and design of each disposal site. Experience with field testing would contribute to the application of sorbent barrier technology at specific sites. 


\section{REFERENCES}

Freeman, H. D., J. L. Buelt and J. N. Hartley. 1984. "Engineered Sorbent Barriers for Low-Level Waste." In Proceedings of the Sixth Annual Participants' Information Meeting DOE Low-Level Waste Management Program, CONF-8409115. National Technical Information Service, Springfield, Virginia.

Hillel, D. 1980. Fundamentals of Soil Physics. Academic Press, Inc., New York.

Mercer, B. W., et al. 1978 "Zeolite Ion Exchange in Radioactive and Municipal Waste Water Treatment." In Natural Zeolite: 0ccurrence, Properties, Use. Pp. 451-462. Pergainon Press, Oxford, England.

Robertson, D. E., K. H. Abel and A. P. Toste. 1982. "Radionuclide Migration in Groundwater." In Proceedings of Fourth Annual Participants Information Meeting DOE Low-Level Waste Management Program, CONF-820854, August 31 September 2, 1982, Denver, Colorado, Pp. 607-618.

Schultz, W. W. 1980. Removal of Radionuclides from Hanford Defense Waste Solutions. RHO-SA-51, Rockwell Hanford Operations, Richland, Washington.

Swanson, J. L. 1984. "Organic Complexant-Enhanced Mobility of Toxic Elements in Low-Level Wastes." In Proceedings of the Sixth Annual Participants" Information Meeting DOE Low-Level Waste Management Program. CONF-8409115, National Technical Information Service, Springfield, Virginia.

Winslow, C. C. 1980. The Sorption of Cesium and Strontium from Concentrated Brines by Backfill Barrier Materials. SAND 80-2046, Sandia National Laboratories, Albuquerque, New Mexico. 


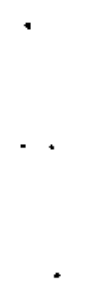

•

. 
APPENDIX A

RESULTS OF LABORATORY STUDIES 
TABLE A.1. Results of Small-Scale Column Tests of Multicomponent Barriers

Strontium Concentration in Column Extracts $(\mathrm{pCi} / \mathrm{g}$ ) and $\mathrm{C} / \mathrm{Co}$ versus Pore Volumes

\begin{tabular}{|c|c|c|c|c|c|c|c|c|c|c|c|c|}
\hline \multirow{2}{*}{$\begin{array}{l}\text { Column Description } \\
\text { Columns } 1-4\end{array}$} & \multicolumn{3}{|c|}{$\begin{array}{c}\text { Leachate } \# 1 \\
\text { Column } 1\end{array}$} & \multicolumn{3}{|c|}{$\begin{array}{c}\text { Leachate } \# 2 \\
\text { Column } 2\end{array}$} & \multicolumn{3}{|c|}{$\begin{array}{c}\text { Leachate } \# 3 \\
\text { Column } 3\end{array}$} & \multicolumn{3}{|c|}{$\begin{array}{c}\text { Leachate \#4 } \\
\text { Column } 4\end{array}$} \\
\hline & P.V. & $\mathrm{pCi} / \mathrm{g}$ & $\mathrm{C} / \mathrm{Co}_{0}$ & P.V. & $\mathrm{pCi} / \mathrm{g}$ & $\mathrm{C} / \mathrm{Co}$ & P.V. & $\mathrm{pCi} / \mathrm{g}$ & $\mathrm{C} / \mathrm{Co}$ & P.V. & $\mathrm{pCi} / \mathrm{g}$ & $\mathrm{C} / \mathrm{Co}$ \\
\hline & 3.86 & 0 & 0.00 & 3.82 & 625 & 0.64 & 3.87 & 0 & 0.00 & 3.87 & 513 & 0.52 \\
\hline 0ak Ridge soil 96\% & 11.62 & 0 & 0.00 & 11.44 & 779 & 0.80 & 11.64 & 0 & 0.00 & 11.59 & 756 & 0.76 \\
\hline Act. charcoal & 23.19 & 0 & 0.00 & 22.86 & 902 & 0.93 & 23.29 & 0 & 0.00 & 23.14 & 902 & 0.91 \\
\hline & 34.76 & 0 & 0.00 & 34.27 & 911 & 0.94 & 34.93 & 0 & 0.00 & 34.75 & 833 & 0.84 \\
\hline & 46.31 & 2 & 0.00 & 45.67 & 878 & 0.91 & 46.57 & 0 & 0.00 & 46.33 & 885 & 0.89 \\
\hline
\end{tabular}

\begin{tabular}{|c|c|c|c|c|c|c|c|c|c|c|c|c|c|}
\hline \multirow{2}{*}{\multicolumn{2}{|c|}{$\begin{array}{l}\text { Column Description } \\
\text { Columns } 5-8\end{array}$}} & \multicolumn{3}{|c|}{ Column 5} & \multicolumn{3}{|c|}{ Column 6} & \multicolumn{3}{|c|}{ Column 7} & \multicolumn{3}{|c|}{ Column 8} \\
\hline & & P.V. & $\mathrm{pCi} / \mathrm{g}$ & $\mathrm{C} / \mathrm{Co}_{0}$ & P.V. & $\mathrm{pC} \mathbf{i} / \mathrm{g}$ & $\mathrm{C} / \mathrm{Co}_{0}$ & P.V. & $\mathrm{pCi} / \mathrm{g}$ & $\mathrm{C} / \mathrm{Co}$ & P.V. & $\mathrm{pCi} / \mathrm{g}$ & $\underline{\mathrm{C} / \mathrm{CO}}$ \\
\hline & & 4.85 & 0 & 0.00 & 4.86 & 0 & 0.00 & 4.85 & 0 & 0.00 & 4.81 & 5 & 0.01 \\
\hline Local soil & $88 \%$ & 14.48 & 0 & 0.00 & & 69 & & 14.49 & 0 & & 14.38 & 89 & 0.09 \\
\hline Act. charcoal & $6 \%$ & 28.98 & 0 & 0.00 & 28.96 & 251 & 0.26 & 28.92 & 0 & 0.00 & 28.68 & 288 & 0.29 \\
\hline Greensand & $1 \%$ & 43.51 & 0 & 0.00 & 43.42 & 346 & 0.36 & 43.39 & 0 & 0.00 & 43.08 & 413 & 0.42 \\
\hline A51 zeolite & $5 \%$ & 57.67 & 0 & 0.00 & 57.85 & 522 & 0.54 & 57.86 & 0 & 0.00 & 57.48 & 582 & 0.5 \\
\hline
\end{tabular}

Column Description

Columns $9-12$

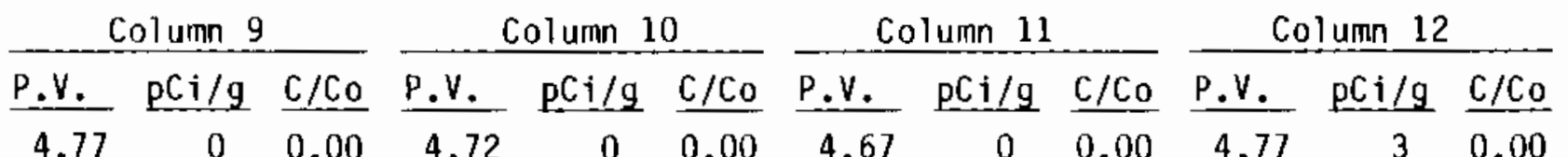

$\begin{array}{llllllllllllll}\text { Local soil } & 85 \% & 11.99 & 0 & 0.00 & 14.11 & 109 & 0.11 & 11.27 & 0 & 0.00 & 14.30 & 106 & 0.11\end{array}$

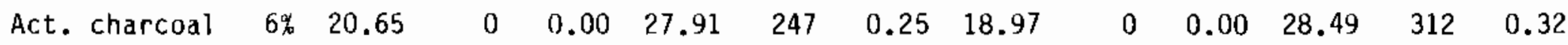

$\begin{array}{llllllllllllll}\text { Red clay } & 5 \% & 34.91 & 0 & 0.00 & 42.07 & 360 & 0.37 & 32.98 & 0 & 0.00 & 42.82 & 343 & 0.35\end{array}$

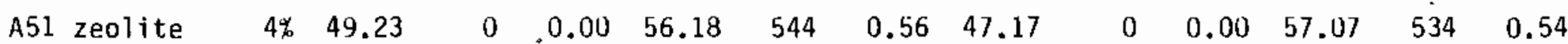




\begin{tabular}{|c|c|c|c|c|c|c|c|c|c|c|c|c|c|}
\hline \multirow{2}{*}{\multicolumn{2}{|c|}{$\begin{array}{l}\text { Column Description } \\
\text { Columns } 13-16\end{array}$}} & \multicolumn{3}{|c|}{ Column 13} & \multicolumn{3}{|c|}{ Column 14} & \multicolumn{3}{|c|}{ Column 15} & \multicolumn{3}{|c|}{ Column 16} \\
\hline & & P.V. & $\mathrm{pCi} / \mathrm{g}$ & $\underline{C} / \mathrm{C}_{0}$ & P.V. & $\mathrm{pCi} / \mathrm{g}$ & $\underline{\mathrm{C} / \mathrm{C}_{0}}$ & P.V. & $\mathrm{pCi} / \mathrm{g}$ & $\mathrm{C} / \mathrm{Co}_{0}$ & P.V. & $\mathrm{pCi} / \mathrm{g}$ & $\underline{\mathrm{C} / \mathrm{Co}}$ \\
\hline & & 3.17 & 0 & 0.00 & 3.54 & 131 & 0.14 & 2.58 & 0 & 0.00 & 3.73 & 182 & 0.18 \\
\hline Local soil & $72 \%$ & 10.33 & 0 & 0.00 & 11.13 & 628 & 0.65 & 9.83 & 0 & 0.00 & 11.60 & 639 & 0.65 \\
\hline Act. charcoal & $26 \%$ & 21.09 & 0 & 0.00 & 22.52 & 802 & 0.83 & 20.73 & 0 & 0.00 & 23.39 & 795 & 0.80 \\
\hline \multirow[t]{2}{*}{ Greens and } & $2 \%$ & 31.85 & 11 & 0.01 & 33.92 & 811 & 0.84 & 31.64 & 0 & 0.00 & 35.21 & 734 & 0.74 \\
\hline & & 42.66 & 51 & 0.06 & 45.29 & 839 & 0.86 & 42.56 & 0 & 0.00 & 47.02 & 816 & 0.82 \\
\hline \multirow{2}{*}{\multicolumn{2}{|c|}{$\begin{array}{l}\text { Columin Description } \\
\text { Columns } 17-20\end{array}$}} & \multicolumn{3}{|c|}{ Column 17} & \multicolumn{3}{|c|}{ Column 18} & \multicolumn{3}{|c|}{ Columin 19} & \multicolumn{3}{|c|}{ Column 20} \\
\hline & & P.V. & $\mathrm{pCi} / \mathrm{g}$ & $\mathrm{C} / \mathrm{CO}_{0}$ & P.V. & $\mathrm{pCi} / \mathrm{g}$ & $\underline{\mathrm{C} / \mathrm{Co}}$ & P.V. & $\mathrm{pCi} / \mathrm{g}$ & $\mathrm{C} / \mathrm{CO}_{0}$ & P.V. & $\mathrm{pCi} / \mathrm{g}$ & $\mathrm{C} / \mathrm{Co}$ \\
\hline & & 3.63 & 0 & 0.00 & 3.54 & 67 & 0.07 & 2.95 & 0 & 0.00 & 3.48 & 81 & 0.08 \\
\hline Local soil & $68 \%$ & 12.01 & 1 & 0.00 & 11.63 & 664 & 0.68 & 10.58 & 0 & 0.00 & 11.58 & 659 & 0.67 \\
\hline Act. charcoal & $26 \%$ & 24.46 & 11 & 0.01 & 23.78 & 839 & 0.86 & 20.19 & 0 & 0.00 & 23.76 & 816 & 0.82 \\
\hline \multirow[t]{2}{*}{ Red clay } & $6 \%$ & 37.04 & 188 & 0.21 & 35.95 & 822 & 0.85 & 31.82 & 0 & 0.00 & 35.92 & 811 & 0.82 \\
\hline & & 49.58 & 286 & 0.32 & 48.13 & 848 & 0.87 & 43.43 & 0 & 0.00 & 47.95 & -- & -- \\
\hline \multirow{3}{*}{\multicolumn{2}{|c|}{$\begin{array}{l}\text { Column Description } \\
\text { Columns } 21-24\end{array}$}} & \multicolumn{3}{|c|}{ Column 21} & \multicolumn{3}{|c|}{ Column 22} & \multicolumn{3}{|c|}{ Column 23} & \multicolumn{3}{|c|}{ Column 24} \\
\hline & & P.V. & $\mathrm{pCi} / \mathrm{g}$ & $\underline{\mathrm{C} / \mathrm{C}_{0}}$ & P.V. & $\mathrm{pC} i / \mathrm{g}$ & $\mathrm{C} / \mathrm{Co}$ & P.V. & $\mathrm{pCi} / \mathrm{g}$ & $\underline{\mathrm{C} / \mathrm{Co}_{0}}$ & P.V. & $\mathrm{pCi} / \mathrm{g}$ & $\mathrm{C} / \mathrm{Co}$ \\
\hline & & 3.46 & 0 & 0.00 & 3.96 & 61 & 0.06 & 3.81 & 0 & 0.00 & 3.99 & 116 & 0.12 \\
\hline Local soil & $69 \%$ & 10.74 & 0 & 0.00 & 12.01 & 456 & 0.47 & 11.47 & 0 & 0.00 & 12.11 & 496 & 0.50 \\
\hline Act. charcoal & $25 \%$ & 21.73 & 0 & 0.00 & 24.13 & 742 & 0.76 & 23.05 & 7 & 0.01 & 24.28 & 723 & 0.73 \\
\hline \multirow[t]{2}{*}{ Dowex XFS res } & n $6 \%$ & 32.68 & 0 & 0.00 & 36.21 & 790 & 0.81 & 34.58 & 7 & 0.01 & 36.42 & 736 & 0.74 \\
\hline & & 43.62 & 0 & 0.00 & 48.28 & -- & -- & 46.08 & -- & -- & 48.59 & -- & -- \\
\hline
\end{tabular}


TABLE A.2. Results of Sma11-Scale Column Tests of Multicomponent Barriers

Cobalt Concentration in Column Extracts $\left(C / C_{0}\right)$ vs. Pore Volumes

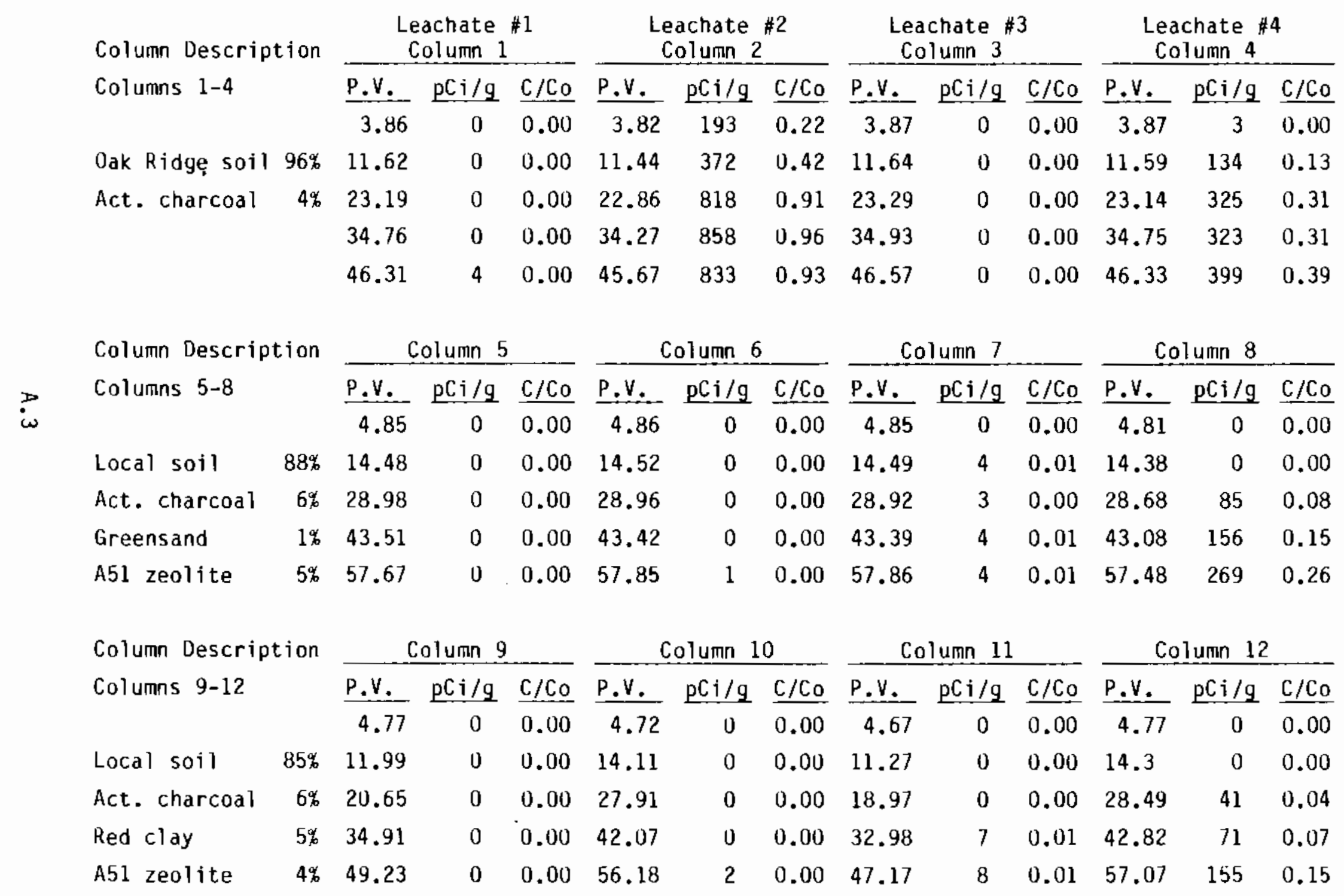




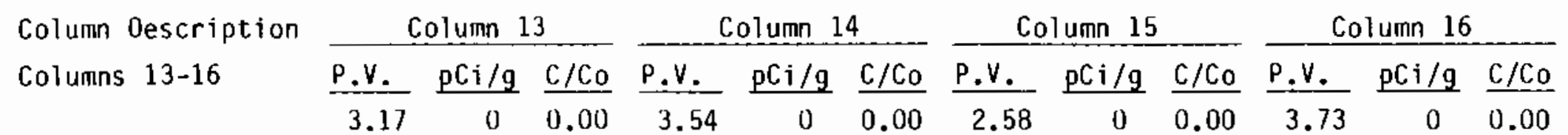

$$
\begin{aligned}
& \begin{array}{llllllllllllll}
\text { Local soil } & 72 \% & 10.33 & 0 & 0.00 & 11.13 & 0 & 0.00 & 9.83 & 0 & 0.00 & 11.6 & 0 & 0.00
\end{array} \\
& \begin{array}{llllllllllllll}
\text { Act. charcoal } & 26 \% & 21.09 & 0 & 0.00 & 22.52 & 0 & 0.00 & 20.73 & 0 & 0.00 & 23.39 & 6 & 0.01
\end{array} \\
& \begin{array}{llllllllllllll}
\text { Greensand } & 2 \% & 31.85 & 0 & 0.00 & 33.92 & 0 & 0.00 & 31.64 & 0 & 0.00 & 35.21 & 12 & 0.01
\end{array} \\
& \begin{array}{llllllllllll}
42.66 & 0 & 0.00 & 45.29 & 2 & 0.00 & 42.56 & 0 & 0.00 & 47.02 & 25 & 0.02
\end{array}
\end{aligned}
$$

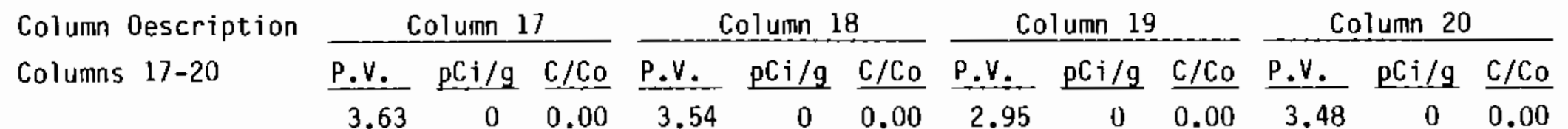

\begin{tabular}{|c|c|c|c|c|c|c|c|c|c|c|c|c|}
\hline \multirow{2}{*}{$\begin{array}{l}\text { Column Description } \\
\text { Columns } 21-24\end{array}$} & \multicolumn{3}{|c|}{ Column 21} & \multicolumn{3}{|c|}{ Column 22} & \multicolumn{3}{|c|}{ Column 23} & \multicolumn{3}{|c|}{ Column 24} \\
\hline & P.V. & $\mathrm{pCi} / \mathrm{g}$ & $\underline{c / C_{0}}$ & P.V. & $\mathrm{pCi} / \mathrm{g}$ & $C / C_{0}$ & P.V. & $\mathrm{pCi} / \mathrm{g}$ & $\mathrm{C} / \mathrm{Co}$ & P.V. & $\mathrm{pCi} / \mathrm{g}$ & $\mathrm{C} / \mathrm{Co}_{0}$ \\
\hline & 3.46 & 0 & 0.00 & 3.96 & 4 & 0.00 & 3.81 & 0 & 0.00 & 3.99 & 0 & 0.00 \\
\hline Local soil & 10.74 & 0 & 0.00 & 12.01 & 9 & 0.01 & 11.47 & 0 & 0.00 & 12.11 & 0 & 0.00 \\
\hline Act. charcoal & 21.73 & 0 & 0.00 & 24.13 & 13 & 0.01 & 23.05 & 0 & 0.00 & 24.28 & 34 & 0.03 \\
\hline Dowex XFS resin $6 \%$ & 32.68 & 0 & 0.00 & 36.21 & 16 & 0.02 & 34.58 & 0 & 0.00 & 36.42 & 40 & 0.04 \\
\hline & 43.62 & 0 & 0.00 & 48.28 & -- & -- & 46.08 & 0 & 0.00 & 48.59 & -- & - \\
\hline
\end{tabular}

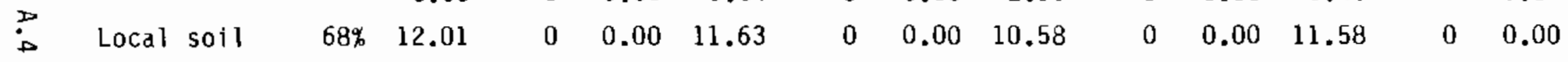

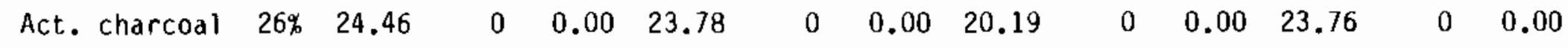

$$
\begin{aligned}
& \begin{array}{llllllllllllll}
\text { Red clay } & 6 \% & 37.04 & 0 & 0.00 & 35.95 & 0 & 0.00 & 31.82 & 0 & 0.00 & 35.92 & 0 & 0.00
\end{array} \\
& \begin{array}{llllllllllll}
49.58 & 0 & 0.00 & 48.13 & 0 & 0.00 & 43.43 & 0 & 0.00 & 47.95 & 0 & 0.00
\end{array}
\end{aligned}
$$



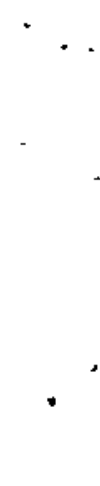

-

. 


\section{APPENDIX B}

RESULTS OF ENGINEERING EVALUATIONS 
TABLE B.1. Analytical Results of First Series of Engineering Evaluations $\mathrm{pCi} / \mathrm{mL}$

\begin{tabular}{|c|c|c|c|c|c|c|c|c|c|}
\hline \multirow[b]{3}{*}{ Bed Volume } & \\
\hline & \multicolumn{3}{|c|}{ Column A } & \multicolumn{3}{|c|}{ Column $B$} & \multicolumn{3}{|c|}{ Column C } \\
\hline & $S r$ & $\mathrm{Cs}$ & $\mathrm{Co}$ & $\mathrm{Sr}$ & $\mathrm{Cs}$ & Co & $\mathrm{Sr}$ & Cs & $\mathrm{Co}$ \\
\hline 0.2 & 0.0 & 0.0 & 0.0 & 0.0 & 0.0 & 0.0 & 0.0 & 0.0 & 0.0 \\
\hline 0.4 & 0.0 & 0.0 & 0.0 & 0.0 & 0.0 & 0.0 & 0.0 & 0.0 & 0.0 \\
\hline 0.6 & 0.0 & 0.0 & 0.0 & 0.0 & 0.0 & 0.0 & 1.1 & 0.0 & 2.3 \\
\hline 0.7 & 0.0 & 0.0 & 0.0 & 0.0 & 0.0 & 0.0 & ND & ND & ND \\
\hline 0.9 & 0.0 & 0.0 & 0.0 & 0.0 & 0.0 & 0.0 & ND & ND & ND \\
\hline 1.1 & 0.0 & 0.0 & 0.0 & 0.0 & 0.0 & 0.0 & 59.8 & 0.0 & 32.8 \\
\hline 1.3 & 0.0 & 0.0 & 0.0 & 0.0 & 0.0 & 0.0 & 81.5 & 0.0 & 36.8 \\
\hline 1.5 & 0.0 & 0.0 & 0.0 & 0.0 & 0.0 & 0.0 & 137.0 & 0.0 & 48.0 \\
\hline 1.7 & 0.0 & 0.0 & 0.0 & 0.3 & 0.0 & 12.6 & 200.0 & 0.0 & 58.8 \\
\hline 1.9 & 0.0 & 0.0 & 0.0 & 0.9 & 0.0 & 2.1 & 234.0 & 0.0 & 95.6 \\
\hline 2.0 & 0.0 & 0.0 & 0.0 & 2.3 & 0.0 & 2.0 & 274.0 & 0.0 & 111.0 \\
\hline 2.2 & 0.0 & 0.0 & 0.0 & 2.0 & 0.0 & 2.3 & 235.0 & 0.0 & 99.8 \\
\hline 2.4 & 0.0 & 0.0 & 0.0 & 3.6 & 0.0 & 1.2 & 260.0 & 0.0 & 94.9 \\
\hline 2.6 & 0.0 & 0.0 & 0.0 & 7.2 & 0.0 & 5.0 & 304.0 & 0.0 & 95.9 \\
\hline 2.8 & 0.0 & 0.0 & 0.0 & 6.2 & 0.0 & 1.4 & 290.0 & 0.0 & 95.3 \\
\hline 3.0 & 0.0 & 0.0 & 0.0 & 6.7 & 0.0 & 1.0 & 302.0 & $0 . \mathrm{D}$ & 98.1 \\
\hline 3.2 & 0.0 & 0.0 & 0.0 & 6.6 & 0.0 & 1.1 & 293.0 & 0.0 & 91.1 \\
\hline 3.4 & 0.0 & 0.0 & 0. & 7.0 & 0.0 & 0.8 & 214.0 & 0.0 & 57.2 \\
\hline 3.5 & 0.0 & 0.0 & 0.0 & 7.1 & 0.0 & 0.5 & 252.0 & 0.0 & 63.0 \\
\hline 3.7 & 0.0 & 0.0 & 0.0 & 8.1 & 0.0 & 0.7 & 245.0 & 0.0 & 54.8 \\
\hline 3.9 & 0.3 & 0.0 & 0.0 & 12.4 & 0.0 & 2.0 & 301.0 & 0.0 & 39.1 \\
\hline 4.1 & 1.7 & 0.0 & 0.0 & 18.2 & 0.0 & 1.8 & & 0.0 & 29.4 \\
\hline 4.3 & 1.9 & 0.0 & 0.0 & 16.6 & 0.0 & 0.7 & 315.0 & 0.0 & 27.2 \\
\hline
\end{tabular}

Simulated Leachate ( $\mathrm{pCi} / \mathrm{mL}$ )

\begin{tabular}{|c|c|c|c|}
\hline & $\mathrm{Sr}$ & $\mathrm{Cs}_{5}$ & Co \\
\hline Batch \#1 & 476.0 & 969.0 & 490. \\
\hline Batch \#2 & 629.0 & 581.0 & 520.0 \\
\hline Batch \#3 & 715.0 & 921.0 & 807.0 \\
\hline $\mathrm{ch} \# 4$ & 1000.0 & 993.0 & 818.0 \\
\hline
\end{tabular}


TABLE B.2. Radionuclide Concentrations in First Series of Column Cores ( $\mathrm{pCi} / \mathrm{mL}$ )

\begin{tabular}{|c|c|c|c|c|}
\hline $\begin{array}{c}\text { Core } \\
\text { ID } \\
\end{array}$ & Depth & $\begin{array}{l}\text { Sr }-85 \\
\text { Conc }\end{array}$ & $\begin{array}{c}\mathrm{Cs}-137 \\
\text { Conc } \\
\end{array}$ & $\begin{array}{l}\text { Co-60 } \\
\text { Conc }\end{array}$ \\
\hline \multicolumn{5}{|l|}{ Column A } \\
\hline $\begin{array}{l}A-5 \\
A-4 \\
A-3 \\
A-2 \\
A-1\end{array}$ & $\begin{array}{l}1.3 \\
2.6 \\
3.9 \\
5.2 \\
6.5\end{array}$ & $\begin{array}{r}4,421.3 \\
2,501.5 \\
696.7 \\
144.0 \\
40.0\end{array}$ & $\begin{array}{r}15,891.6 \\
255.0 \\
30.4 \\
8.0 \\
29.3\end{array}$ & $\begin{array}{r}14,020.6 \\
2,900.1 \\
247.7 \\
56.3 \\
32.2\end{array}$ \\
\hline \multicolumn{5}{|l|}{ Column B } \\
\hline $\begin{array}{l}B-4 \\
B-3 \\
B-2 \\
B-1\end{array}$ & $\begin{array}{l}1.3 \\
2.6 \\
3.9 \\
5.2\end{array}$ & $\begin{array}{r}2,606.4 \\
1,581.0 \\
623.4 \\
188.7\end{array}$ & $\begin{array}{r}10,496.5 \\
90.0 \\
25.7 \\
17.2\end{array}$ & $\begin{array}{r}6,390.9 \\
574.0 \\
201.7 \\
89.8\end{array}$ \\
\hline \multicolumn{5}{|l|}{ Column C } \\
\hline $\begin{array}{l}C-5 \\
C-4 \\
C-3 \\
C-2 \\
C-1\end{array}$ & $\begin{array}{l}1.3 \\
2.6 \\
3.9 \\
5.2 \\
6.5\end{array}$ & $\begin{array}{l}472.2 \\
533.4 \\
470.1 \\
382.0 \\
354.8\end{array}$ & $\begin{array}{r}8,737.7 \\
69.1 \\
6.6 \\
57.1 \\
1,124.9\end{array}$ & $\begin{array}{r}5,065.2 \\
366.5 \\
60.9 \\
79.1 \\
558.7\end{array}$ \\
\hline
\end{tabular}

(a) Al1 cores taken in the center of the column. 
TABLE B.3. Leachate Concentrations From Second Series of Engineering Evaluations $(\mathrm{a})(\mathrm{pCi} / \mathrm{mL})$

\begin{tabular}{|c|c|c|c|c|c|c|c|c|c|}
\hline \multirow{2}{*}{$\begin{array}{l}\text { Bed } \\
\text { volume }\end{array}$} & \multicolumn{3}{|c|}{ Column A } & \multicolumn{3}{|c|}{ Column B } & \multicolumn{3}{|c|}{ Column C } \\
\hline & ${ }^{85} \mathrm{Sr}$ & ${ }^{137} \mathrm{Cs}$ & ${ }^{60} \mathrm{Co}$ & ${ }^{85}{ }_{S r}$ & ${ }^{137} \mathrm{Cs}$ & ${ }^{60} \mathrm{Co}$ & ${ }^{85}{ }_{S r}$ & ${ }^{137} \mathrm{Cs}$ & ${ }^{60} \mathrm{Co}_{\mathrm{o}}$ \\
\hline 0.37 & 0 & 0.00 & 0.00 & 4.16 & 0 & 0.99 & 0.00 & 0 & 0.00 \\
\hline 0.56 & 0 & 0.00 & 0.00 & 5.63 & 0 & 1.74 & 0.32 & 0 & 0.51 \\
\hline 1.12 & 0 & 0.00 & 0.00 & 26.66 & 0 & 17.85 & 0.00 & 0 & 0.45 \\
\hline 1.31 & 0 & 0.00 & 0.15 & 36.01 & 0 & 20.53 & 0.00 & 0 & 3.03 \\
\hline 1.49 & 0 & 0.00 & 0.18 & 17.11 & 0 & 11.04 & 0.53 & 0 & 2.59 \\
\hline 1.68 & 0 & 0.00 & 0.17 & 14.74 & 0 & 9.74 & 0.36 & 0 & 1.73 \\
\hline 1.87 & 0 & 0.00 & 0.00 & 22.28 & 0 & 12.28 & 1.09 & 0 & 1.85 \\
\hline 2.24 & 0 & 0.00 & 0.18 & 51.84 & 0 & 28.72 & 1.73 & 0 & 1.53 \\
\hline 2.50 & 0 & 0.22 & 0.57 & 45.56 & 0 & 20.87 & 3.37 & 0 & 2.15 \\
\hline 2.80 & 0 & 0.00 & 0.45 & 93.26 & 0 & 46.19 & 6.44 & 0 & 2.00 \\
\hline 3.17 & 0 & 0.00 & 2.39 & 117.62 & 0 & 53.47 & 15.01 & 0 & 2.12 \\
\hline 3.54 & 0 & 0.14 & 1.77 & 116.00 & 0 & 56.82 & 24.74 & 0 & 2.35 \\
\hline 3.73 & 0 & 0.00 & 0.00 & 87.33 & 0 & 53.14 & 32.22 & 0 & 6.07 \\
\hline
\end{tabular}

Simulated Leachate

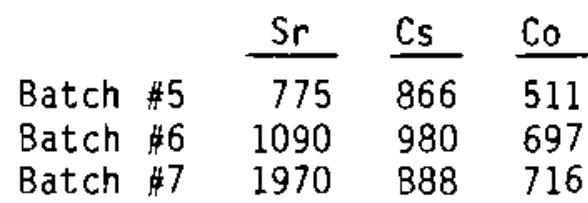

(a) Detection limit $\sim 0.1 \mathrm{pCi} / \mathrm{mL}$ for all radionuclides. 
TABLE B.4. Radionuclide Concentrations in Second Series of Column Cores

\begin{tabular}{|c|c|c|c|c|}
\hline $\begin{array}{c}\text { Sample } \\
\text { ID }\end{array}$ & $\begin{array}{c}\text { Depth, } \\
\mathrm{cm}\end{array}$ & $\begin{array}{c}{ }^{85} \mathrm{Sr} \\
\text { Conc, } \mathrm{pCi} / \mathrm{g}\end{array}$ & $\begin{array}{c}{ }^{137} \mathrm{Cs} \\
\text { Conc, } \mathrm{pCi} / \mathrm{g}\end{array}$ & $\begin{array}{l}{ }^{60} \mathrm{Co} \\
\text { Conc, } \mathrm{PCi} / \mathrm{g}\end{array}$ \\
\hline
\end{tabular}

COLUMN A CENTER

$\begin{array}{rrrrr}\text { A-C }-0 & 2.86 & 10402.2 & 15474.3 & 5993.8 \\ \text { A-C }-1 & 5.87 & 592.9 & 3.9 & 220.7 \\ \text { A-C }-2 & 8.73 & 47.9 & 8.4 & 64.5 \\ \text { A-C - } & 11.58 & 0.0 & 0.0 & 13.3 \\ \text { A-C }-4 & 14.12 & 4.1 & 1.9 & 9.1\end{array}$

COLUMN B $6^{\prime \prime}$ FROM EDGE NEAR INLET

$\begin{array}{lcrrr}\text { B-E-0 } & 3.65 & 12684.7 & 55206.2 & 5660.3 \\ \text { B-E-1 } & 7.3 & 8705.4 & 3244.7 & 5243.6 \\ \text { B-E-2 } & 10.48 & 6403.5 & 58.3 & 4377.6 \\ \text { B-E-3 } & 13.34 & 5382.3 & 0.0 & 4155.9 \\ \text { B-E-4 } & 16.19 & 2385.9 & 0.0 & 2000.0\end{array}$

COLUMN B CENTER

$\begin{array}{rrrrr}B-C-0 & 3.18 & 12606.0 & 35808.0 & 6409.3 \\ B-C-1 & 6.35 & 8159.0 & 1123.4 & 5322.7 \\ B-C-2 & 9.84 & 6072.3 & 41.8 & 4282.2 \\ B-C-3 & 13.02 & 4041.3 & 0.0 & 3224.5 \\ B-C-4 & 15.24 & 1492.2 & 213.0 & 1128.0\end{array}$

COLUMN C CENTER

$\begin{array}{rrrrr}C-C-0 & 2.54 & 6030.4 & 12040.4 & 4820.6 \\ C-C-1 & 5.24 & 3141.8 & 17.0 & 1711.7 \\ C-C-2 & 7.78 & 1468.7 & 0.0 & 271.6 \\ C-C-3 & 10.32 & 652.2 & 2.1 & 53.2 \\ C-C-4 & 12.86 & 262.5 & 2.0 & 19.4\end{array}$


DISTRIBUTION

No. of

Copies

OFFSI TE

6 Geologic Repository Division DOE Office of Civilian

Radioactive Waste Management Forrestal Building

Washington, OC 20585

ATTN: C. R. Cooley, RW-4

J. R. Hilley

W. J. Purcel1, RW-20

B. C. Rusche, RW-1

D. E. Shelor

R. Stein, RW-23

3 DOE Dffice of Defense Waste \& GTN

Byproducts Management

Washington, DC 20545

ATTN: R. K. Heusser

J. E. Lytle, $O P-12$

R. D. Walton, Jr., DP-123

6 DOE Office of Terminal Waste Disposal \& Remedial Action GTN

Washington, OC 20545

ATTN: J. A. Coleman, NE-25

T. W. McIntosh, NE-25

H. Stelling, NE-25

W. R. Voigt, NE-20

H. F. Walter, NE-25

J. B. Zorn, NE-25

30 DOE Technical Information Center

A. T. Clark

Division of Fuel Materia] Safety

Nuclear Regulatory Commission Washington, DC 20555
No. of

Copies

V. Stello

Office of Executive Director for Operations

Mail Station 6209

Nuclear Regulatory Commission

Washington, DC 20555

G. L. Sjoblom

Environmental Protection Agency

Office of Radiation Programs

401 M Street, S.W.

Washington, DC 20460

J. M. McGough

DOE Albuquerque Operations

Office

P.0. Box 5400

ATbuquerque, NM 87185

P. G. Hagen

Joint Integration office

BTdg. 3, 2nd Floor

2201 San Pedro N.E.

Albuquerque, NM 87110

E. Maestas

DOE West Valley Operations

Office

P.0. Box 191

West Valley, NY 14171

2 DOE Idaho Operations Office

550 Second Street

Idaho FaI1s, ID B3401

ATTN: M. J. Barainca

J. P. Hamric

F. T. Fong

DOE San Francisco Operations

1333 Broadway

Oakland, CA 94612 
No. of

Copies

M. R. Jugan

DOE Oak Ridge Operations office

P.0. Box E

Oak Ridge, TN 37830

W. J. Brumley

DOE Savannah River Operations Office

P.0. Box A

Aiken, SC 29801

M. J. Steindler

Argonne National Laboratory

9700 South Cass Avenue

Argonne, IL 60439

C. S. Abrams

Argonne National Laboratory

P.0. 80x 2528

Idaho Falls, I0 83401

B. D. Shipp

Battelle Memorial Institute

Office of Crystalline

Repository Oevelopment

9800 South Cass Avenue

Argonne, IL 60439

3 Battelle Memorial Institute

Project Management 0ivision

505 King Avenue

Columbus, $0 \mathrm{H} \cdot 43201$

ATTN: W. A. Carbeiner

W. S. Madia

B. Rawles

D. T. Oakley, MS 671

Los Alamos Scientific Laboratory

P.0. Box 1663

Los Alamos, NM 87544

8 Oak Ridge National Laboratory

P.0. Box $Y$

Oak Ridge, TN $\overline{3} 7830$

ATTN: J. 0. Blomeke

W. D. Burch

N. H. Cutshall
No. of

Copies

Oak Ridge National Laboratory (contd)

ATTN: F. J. Homan

R. T. Jubin

L. J. Mezga

T. H. Row

8. P. Spatding

4 Sandia Laboratories

P.0. Box 5800

Albuquerque, NM 87185

ATTN: D. R. Anderson

R. W. Lynch

W. Weart

Technical Library

J. R. Berreth

Westinghouse Idaho Nuclear Co., Inc.

P.0. Box 4000

Idaho Falls, ID 83401

6 E. I. du Pont de Nemours Company

Savannah River Laboratory

Aiken, SC 29801

ATTN: H. D. Boersma

J. G. Glasscock

E. J. Hennelly

J. R. Knight

M. J. PTodinec

C. T. Randali

6 EG\&G Idaho

P.0. Box 1625

Idaho Falls, ID 83401

ATTN: J. Bradford

R. Dodge

D. K. Halford

E. A. Jennrich

J. Logan

S. C. Minkin 
No. of

Copies

2 Electric Power Research Institute

3412 Hillview Avenue

P.0. Box 10412

Palo Alto, CA 94304

ATTN: R. A. Shaw

R. Williams

5 West Valley Nuclear Services Company

P.0. Box 191

West Valley, NY 14171

ATTN: C. C. Chapman

J. C. Cwynar

J. E. Krauss

S. J. Marchette

J. M. Pope

J. L. Larocca, Chairman

Energy Research \& Development

Authority

Empire State Plaza

Albany, NY 12223

3 Brookhaven National Laboratory Upton, NY 11973

ATTN: P. Colombo

C. R. Kemp $f$

T. Sullivan

A. Pasternak

California Radioactive

Materials Management Forum

455 Capitol Mall

Suite 380

Sacramento, CA 95814

L. D. Ramspott

Lawrence Livermore National Laboratory

University of California

P.0. Box 808

Livermore, CA 94550
No. of

Copies

ONSITE

3 DOE Richland Operations Office

E. A. Bracken

N. T. Karagianes

J. D. White

11 Rockwel1 Hanford Operations

R. N. Gurley

J. M. Henderson

N. W. Kirch

H. E. MCGuire

R. D. Prosser

I. E. Reep

R. J. Thompson

T. B. Venziano

D. D. Wodrich

R. D. Wojtasek

File Copy

UNC United Nuclear Industries

T. E. Dabrowski/W. J. Kyriazis

2 Westinghouse Hanford Company

R. E. Lerch

J. D. Watrous

38 Pacific Northwest Laboratory

C. R. Allen

W. W. Ballard, Jr.

W. F. Bonner

L. A. Bray

J. L. Buelt

H. C. Burkholder

M. R. Elmore

V. F. Fitzpatrick

H. 0. Freeman

H. A. Haerer

M. S. Hanson

J. N. Hartley

J. H. Jarrett

W. W. Laity

L. T. Lakey 
No. of

Copies

Pacific Northwest Laboratory (contd)

J. M. Latkovich

D. McCarthy

E. D. McClanahan

J. L. McElroy

J. E. Minor

D. H. Mitchell

S. J. Mitchell

D. A. Myers

R. D. Peters

J. A. Powel1

H. A. Ross

J. L. Ryan

R. J. Serne

R. L. Skaggs

J. L. Straalsund

J. L. Swanson

Publishing Coordination (2)

Technical Information (5) 